*ak RMIS View/Frint Document Cover Sheet tow

This document was retrieved from the Documentation and Records Manaqement (DRM) ISEARCH System. It is intended for Information only and may not be the most recent or updated version. Contact a Document Service Center (see Hanford Info for locations) if you need additional retrieval information.

Accession \#: D196002465

Document \#: SD-WM-SFR-009

Title/Desc:

TWRS VIEW SYSTEM REQUIREMENTS SPEC

Pages: 41 
Staticn-34, \#(c8) $12-27-(15$

ENGINEERING DATA TRANSMITTAL

Page 1 of

1. EDT 602682

2. To: (Receiving Organization)

SE Risk Management and

Model ing

5. Proj./Prog./Dept./Div.:

TWRS

8. Originator Remarks:

$N / A$
3. From: (Originating Organization)

Technical Baseline Integration

6. Cog. Engr.:
A. K. Lee
74402

tion)

Dimare
11. Receiver Renarks:

$+$

-

4. Related EDT No.:
N/A $N / A$

10. System/Bldg./Facil f ty: $N / A$

12. Major Assm. Dwg. No.: N/A

13. Permit/Permit Application No.: $\mathrm{N} / \mathrm{A}$

14. Required Response Date: $12 / 15 / 95$

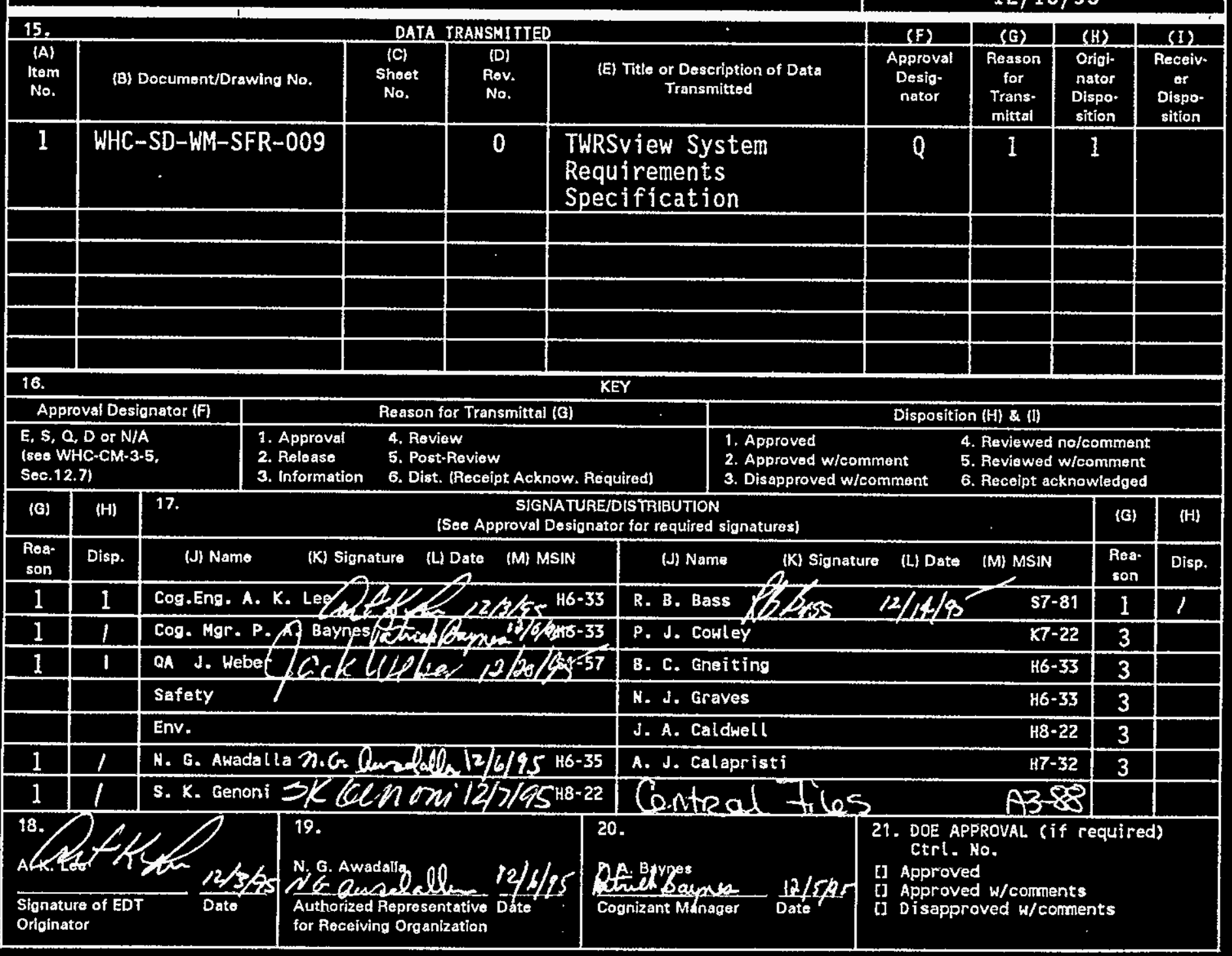


WHC-SD-WM-SFR-009 REV 0

This page intentionally left blank. 


\title{
TWRSview System Requirements Specification
}

\author{
J.A Caldwell, A.K. Lee
}

Westinghouse Hanford Company, Richland, WA 99352

U.S. Department of Energy Contract DE-AC06-87RL10930
EDT/ECN: 602682
UC: 2030
Org Code: 74400
Charge Code: D1M26
BQR Code:
Total Pages: $¥$ I

Key Words: TWRSview, Systems Requirements Specification

Abstract: This document provides the system requirements specification for the TWRSview software system. The TWRSview software system is being developed to integrate electronic data supporting the development of the TWRS technical baseline.

TRADEMARK DISCLAIMER. Reference herein to any specific comercial product, process, or service by trade name, tradenark, manufacturer, or otherwise, does not necessarily constitute or imply its endorsement, recommendation, or favoring by the United States Government or any agency thereof or its contractors or subcontractors.

Printed in the United States of America. To obtain copies of this document, contact: WHC/BCS Document Control Services, P.O. Box 1970, Mailstop H6-08, Ri chland in 99352, Phone (509) 372-2420; Fax (509) 376-4989.
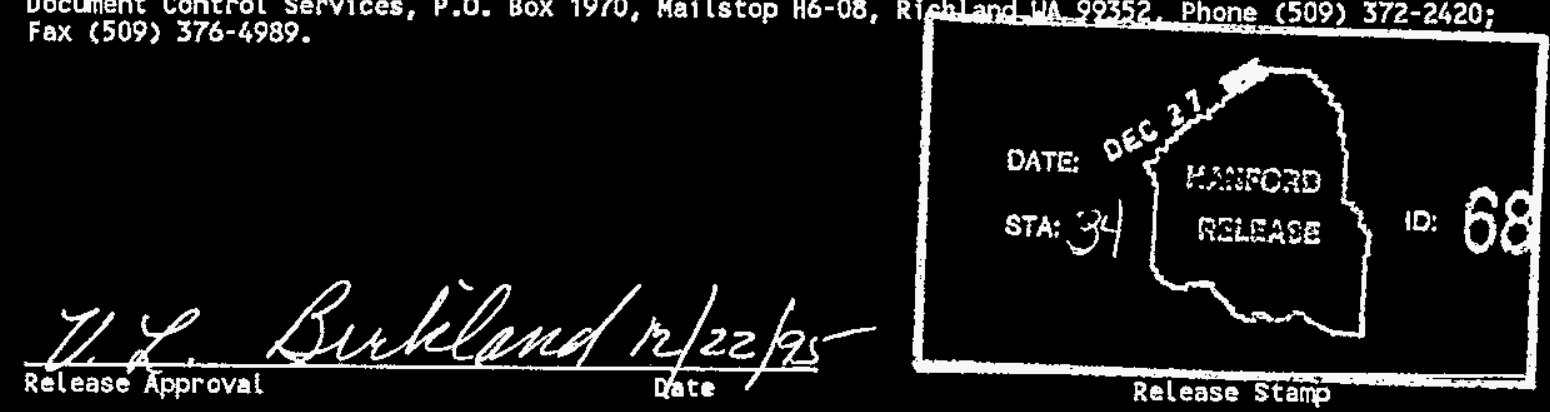

Approved for Public Release 
WHC-SD-WM-SFR-009 REV 0

\begin{tabular}{|l|c|c|}
\hline \multicolumn{1}{|c|}{ Task } & SWASDS & WHC \\
\hline Hardware maintenance & & $X$ \\
\hline Backup/recovery & & $X$ \\
\hline
\end{tabular}


WHC-SD-WM-SFR-009, Rev. 0

This page intentionally left blank. 
Responsibility Matrix

\begin{tabular}{|c|c|c|}
\hline Task & SWASDS & WHC \\
\hline \multicolumn{3}{|l|}{ Software Development } \\
\hline Develop code & $\bar{x}$ & \\
\hline Define data relationship/structures & $x$ & $x$ \\
\hline Develop GUI views & $\bar{X}$ & $\bar{x}$ \\
\hline Supply model diagrams & & $x$ \\
\hline Create models & $X$ & \\
\hline Develop IDMMS links & $X$ & $\bar{x}$ \\
\hline Data sources & & $\bar{x}$ \\
\hline Data Conversion/Preparation & $x$ & $x$ \\
\hline Develop help scripts & $\bar{x}$ & \\
\hline Develop error message scripts & $x$ & \\
\hline \multicolumn{3}{|l|}{ Installation } \\
\hline Provide file server/setup & & $x$ \\
\hline HLAN coordination & & $X$ \\
\hline Installation script/auto update & $x$ & $\bar{x}$ \\
\hline Provide software and user licenses & $\bar{x}$ & \\
\hline \multicolumn{3}{|l|}{ Software Testing } \\
\hline Component testing & $x$ & \\
\hline Integration testing & $\mathrm{x}$ & $x$ \\
\hline Total system testing & & $x$ \\
\hline \multicolumn{3}{|l|}{ Training } \\
\hline Setup training & & $x$ \\
\hline Conduct training & $x$ & \\
\hline On-going training & & $\bar{x}$ \\
\hline \multicolumn{3}{|l|}{ Documentation } \\
\hline Project Plan & & $\bar{X}$ \\
\hline Software Requirements Specifications & & $x$ \\
\hline Discrepancy reporting & & $X$ \\
\hline Test and Acceptance reporting & & $x$ \\
\hline System Design Description & $x$ & \\
\hline User Guide & & $x$ \\
\hline \multicolumn{3}{|l|}{ Maintenance } \\
\hline Software deveTopment & $\bar{x}$ & \\
\hline Software maintenance & & $x$ \\
\hline
\end{tabular}




\section{CONTENTS}

1.0 INTRODUCTION

1.1 PURPOSE

1.2 SCOPE

1.3 OVERVIEW

2.0 GENERAL DESCRIPTION

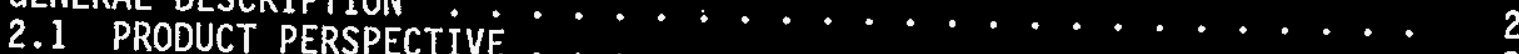

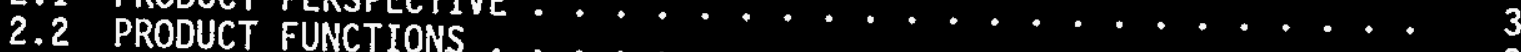

2.3 USER CHARACTERISTICS $\cdot \cdot \cdot \cdot \cdot \cdot \cdot \cdot \cdot \cdot \cdot \cdot \cdot \cdot \cdot \cdot \cdot \cdot \cdot \cdot \cdot 3$

2.4 GENERAL CONSTRAINTS ..$\cdot \cdot \cdot \cdot \cdot \cdot \cdot \cdot \cdot \cdot \cdot \cdot \cdot \cdot \cdot \cdot \cdot \cdot 4$

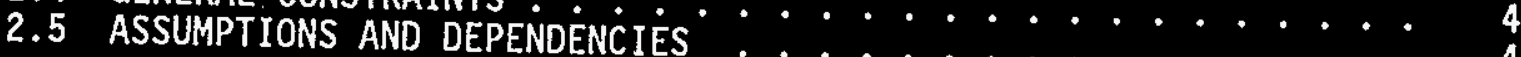

3.0 SPECIFIC REQUIREMENTS ........................

3.1 FUNCTIONAL REQUIREMENTS . . . . . . . . . . . . . . . . . 5

3.1.1 Mission Analysis Formulation . . . . . . . . . . . . . . . 5

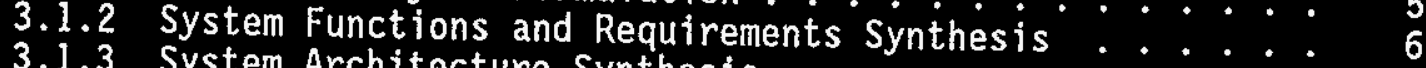

3.1.3 System Architecture Synthes is ............... 6

3.1.5 System Trade Studies Analysis . . . . . . . . . . . . . 7

3.1.6 Program Schedule and Cost Defin : . . . . . . . . . . 8

3.1.7 Inputs.

3.1 .8 Outputs $\cdot . . \cdot \cdot \cdot \cdot \cdot \cdot \cdot \cdot \cdot \cdot \cdot \cdot \cdot \cdot \cdot \cdot \cdot \cdot \cdot 8$

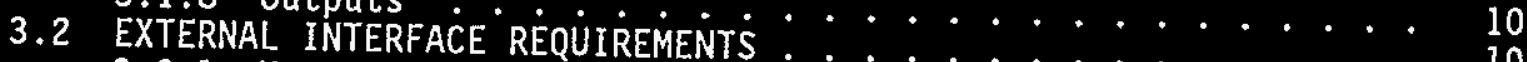

3.2.1 User Interfaces

3.2.2 Hardware Interfaces . . . . . . . . . . . . 10

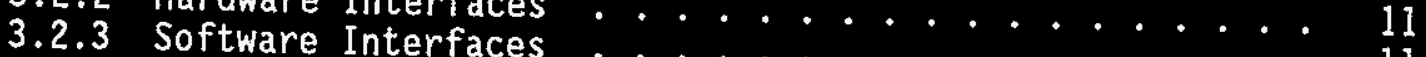

3.2.4 Communication Interfaces . . . . . . . . . . . . . 11

3.3 PERFORMANCE REQUIREMENTS

3.3.1 Readability

3.3.2 Response Times . . . . . . . . . . . . . . . 12

3.4 DESIGN CONSTRAINTS

3.4.1 Standards Compliance . . . . . . . . . . . . 12

3.4.2 Resource Limitations . . . . . . . . . . . . . . . 12

3.5 ATTRIBUTES

3.5.1 Avallability. . . . . . . . . . . . . . 13

3.5.2 Maintenance .................... 13

3.5.3 Compatibility . . . . . . . . . . . . . . 13

3.5.4 Data Integrity..................$^{.}$. 13

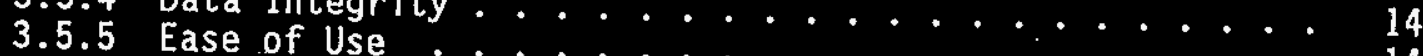

3.6 OTHER REQUIREMENTS ................. 14

3.6.1 Data . . . . . . . . . . . . . . 14

3.6.2 0perations . . . . . . . . . . . . . . 14

3.6.3 Site Adaptation ............................ 15

3.6.4 Reliability and Recovery . . . . . . . . . 15

3.6.5 Audit . . . . . . . . . . . 15

3.6.6 Transferability . . . . . . . . . . . . . . . 15

3.6.7 Conversion......................... 15

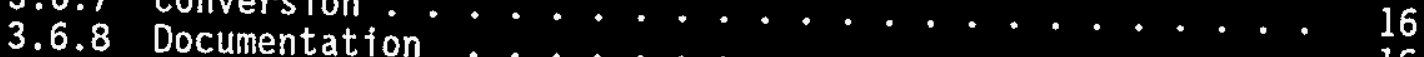

3.6.9 Training...................... 16

3.6.10 Securtty and Privacy . . . . . . . . . . . 17

4.0 REFERENCES . . . . . . . . . . . . . . . . . . . . 17 
WHC-SD-WM-SFR-009 REV 0

APPENDIX B

RESPONSIBILITY MATRIX 
WHC-SD-WM-SFR-009 REV 0

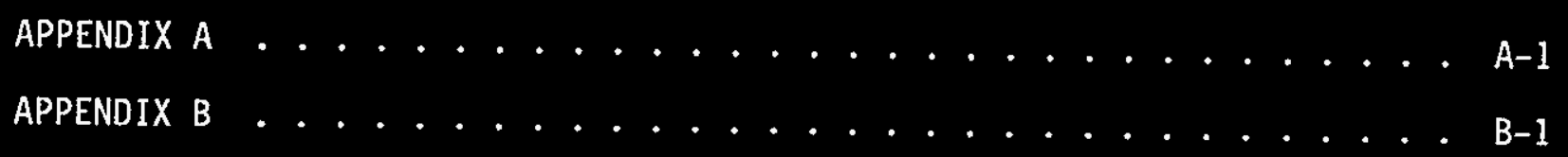


WHC-SD-WM-SFR-009 REV 0

. This page intentionally left blank. 


\section{LIST OF TERMS}

CAD Computer-ajded Design

DOE U.S. Department of Energy

DST double-shell tank

Ecology Washington State Department of Ecology

EPA U.S. Environmental Protection Agency

ESOE End System Operating Environment

GUI graphical user interface

HANTAG Hanford Technica.l Advisory Board

HANTRB Hanford Technical Review Board

HLAN Hanford Local Area Network

IDMMS Integrated Dynamic Modeling and Management System

ISD Information Systems Definition

PMCS Performance Measurement Control System

PNL Pacific Northwest Laboratories

RMACS Requirements Management and Assured Compliance System

SDD System Design Description

SGML Standard General Mark-up Language

SRS Software Requirements Specification

SST single-she]l tank

SWASDS Stone and Webster Advanced Systems Development Services, Inc.

TWRS Tank Waste Remediation System

WHC Westinghouse Hanford Company 


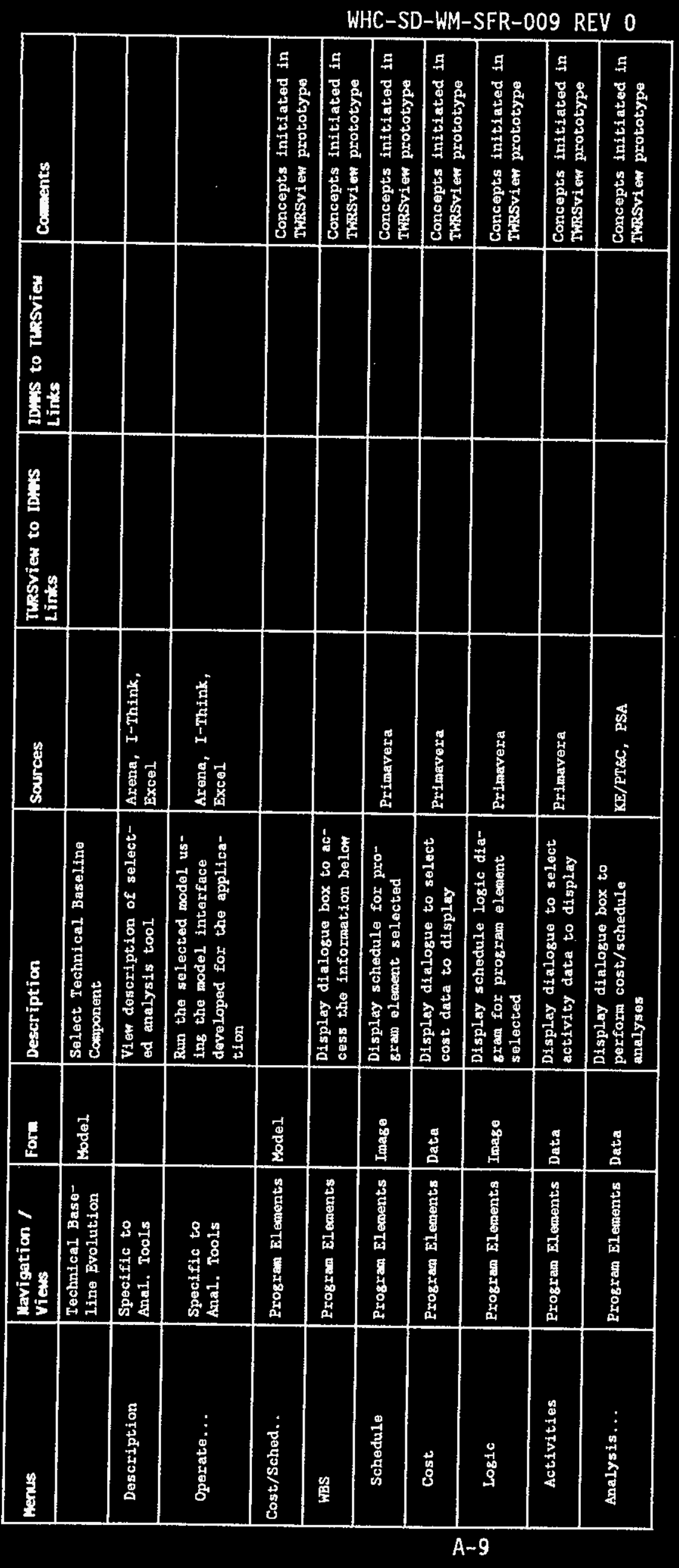


WHC-SD-WM-SFR-009 REV 0

This page intentionally left blank. 


\begin{tabular}{|c|c|c|c|c|c|c|c|}
\hline Menus & $\begin{array}{l}\text { Kavigation / } \\
\text { Vieus }\end{array}$ & Form & Description & Sources & $\begin{array}{l}\text { Trasvies to IDwes } \\
\text { Links }\end{array}$ & $\begin{array}{l}\text { IDins to russvien } \\
\text { Links }\end{array}$ & Cowiments \\
\hline & $\begin{array}{l}\text { Technical Base- } \\
\text { 1Ine Evolution }\end{array}$ & Kodel & $\begin{array}{l}\text { Select Technical Baseline } \\
\text { Component }\end{array}$ & & & & \\
\hline Trade Study Anal. & $\begin{array}{l}\text { Specific to } \\
\text { Irade Study }\end{array}$ & Kodel & & & & & \\
\hline Simal. AnaI. & $\begin{array}{l}\text { Specific to } \\
\text { Trede Study }\end{array}$ & Dialogue & $\begin{array}{l}\text { Display dialogue to select } \\
\text { similation case to perfora } \\
\text { queries below }\end{array}$ & & & & $\begin{array}{l}\text { Concepts initiated in } \\
\text { ThRSviem prototype }\end{array}$ \\
\hline Foundation... & $\begin{array}{l}\text { Specteic to } \\
\text { Irade Study }\end{array}$ & Dlalogue & & & & & $\begin{array}{l}\text { Concepts initiated in } \\
\text { TWRSview prototype }\end{array}$ \\
\hline Description & $\begin{array}{l}\text { Specific to } \\
\text { Trede Study }\end{array}$ & Text & $\begin{array}{l}\text { View description of simula- } \\
\text { tion analysis }\end{array}$ & $\begin{array}{l}\text { Arena, I-Think, } \\
\text { Insight, OWTP }\end{array}$ & & & $\begin{array}{l}\text { Concepts initiated in } \\
\text { TWisviem prototype }\end{array}$ \\
\hline As sumptions & $\begin{array}{l}\text { Specific to } \\
\text { Trade Study }\end{array}$ & Text & $\begin{array}{l}\text { View description of assump- } \\
\text { tions tsed for simulation }\end{array}$ & $\begin{array}{l}\text { Arena, I-Think, } \\
\text { Insight, OfvP }\end{array}$ & & - & $\begin{array}{l}\text { Concepts initiated in } \\
\text { TWRSvien prototype }\end{array}$ \\
\hline Logic Diag. & $\begin{array}{l}\text { Specific to } \\
\text { Trade Study }\end{array}$ & Iaage & $\begin{array}{l}\text { Display diagran of simula- } \\
\text { tion logic }\end{array}$ & $\begin{array}{l}\text { Arena, I-Think, } \\
\text { In'sight, OWTP }\end{array}$ & & & $\begin{array}{l}\text { Concepts initiated in } \\
\text { ThRSview prototype }\end{array}$ \\
\hline Graphics & $\begin{array}{l}\text { Specific to } \\
\text { Txade Study }\end{array}$ & Image & $\begin{array}{l}\text { Display graphs of results } \\
\text { from simulation analysis }\end{array}$ & $\begin{array}{l}\text { Arena, I-Think, } \\
\text { Insight, OWVP }\end{array}$ & & & $\begin{array}{l}\text { Concepts initiated in } \\
\text { TWRSviem prototype }\end{array}$ \\
\hline Results & $\begin{array}{l}\text { Specifle to } \\
\text { Trade Study }\end{array}$ & Data & $\begin{array}{l}\text { Display dialogue to select } \\
\text { simulation data to display }\end{array}$ & $\begin{array}{l}\text { Arena, I-Think, } \\
\text { Insight, ONVP }\end{array}$ & & & $\begin{array}{l}\text { Concepts initiated in } \\
\text { Thisvien prototype }\end{array}$ \\
\hline Frocess Anal. & $\begin{array}{l}\text { Specific to Pxo- } \\
\text { cess Anal: }\end{array}$ & Hodel & $\begin{array}{l}\text { Display wodels and process } \\
\text { andysis specific menus to } \\
\text { navigat through process } \\
\text { analysis results }\end{array}$ & $\begin{array}{l}\text { Process Flow Dia- } \\
\text { Grans }\end{array}$ & & & $\begin{array}{l}\text { Concepts initiated in } \\
\text { ThRSview prototype }\end{array}$ \\
\hline Rosults & $\begin{array}{l}\text { Specific to Pro- } \\
\text { cess Anal. }\end{array}$ & Data & $\begin{array}{l}\text { Display dialogue to select } \\
\text { process analysis data to } \\
\text { display }\end{array}$ & ASPEA & & & $\begin{array}{l}\text { Concepts initiated in } \\
\text { ThISEview prototype }\end{array}$ \\
\hline Risk Analysis & $\begin{array}{l}\text { Specific to Risk } \\
\text { Analysis }\end{array}$ & & $\begin{array}{l}\text { Display models and risk } \\
\text { andiysis specific menus to } \\
\text { navigate through risk anal- } \\
\text { ysis results }\end{array}$ & . & & & $\begin{array}{l}\text { Concepts initiated in } \\
\text { TWRSview prototype }\end{array}$ \\
\hline Rosults & $\begin{array}{l}\text { Specific to Risk } \\
\text { Analysis }\end{array}$ & Data & $\begin{array}{l}\text { Display dialogue to select } \\
\text { risk analysis data to dis- } \\
\text { play }\end{array}$ & $\begin{array}{l}\text { Risk Database, RMA- } \\
\text { CS, IRAP }\end{array}$ & & & $\begin{array}{l}\text { Concepts initiated in } \\
\text { THSview prototype }\end{array}$ \\
\hline LCC Analysis & $\begin{array}{l}\text { Specific to LCC } \\
\text { Analysis }\end{array}$ & & $\begin{array}{l}\text { Display models and LCC an- } \\
\text { alysis specific menus to } \\
\text { navigate through LCC analy- } \\
\text { sis results }\end{array}$ & & & & \\
\hline Results & $\begin{array}{l}\text { Specific to LCC } \\
\text { Analysis }\end{array}$ & & $\begin{array}{l}\text { Display dialogue to select } \\
\text { LCC analysis data to dis" } \\
\text { play }\end{array}$ & Primavera, Excel & & & \\
\hline $\begin{array}{l}\text { Trade study Anal. } \\
\text { Tools... }\end{array}$ & $\begin{array}{l}\text { Spocific to } \\
\text { Anal. Tools }\end{array}$ & & $\begin{array}{l}\text { Display dialogue to select } \\
\text { from analysis tools to use }\end{array}$ & $\begin{array}{l}\text { Arena, I-Think, } \\
\text { Exce1. }\end{array}$ & & & \\
\hline
\end{tabular}




\section{TWRSVIEW SYSTEM REQUIREMENTS SPECIFICATION}

\subsection{INTRODUCTION}

The U.S. Department of Energy (DOE) has established the Tank Waste Remediation System (TWRS) Program to safely manage and dispose of the tank waste stored at the Hanford Site. The mission of the TWRS Program is "to store, treat, and immobilize highly radioactive Hanford waste in an environmentally sound, safe, and cost-effective manner." The scope includes project and program activities for receiving, safely storing, maintaining, treating, and disposing onsite, or packaging for offsite disposal, ali tank waste. Tank waste includes the current contents of 149 single-shel1 tanks (SST), 28 double-she11 tanks (DST), approximately 60 miscellaneous tanks (identified to date), plus any new waste added to these facilities, and all encapsulated cesium and strontium stored onsite and returned from offsite users. As the TWRS program is developed and deployed, it is necessary for program decision makers to understand the cost, schedules, technical performance, environmental, and public and worker health and safety impacts of their decisions. Because of the size and complexity of the TWRS Program, an integrated computer simulation and data management system is required. A mission analysis was performed for developing an Integrated Dynamic Modeling and Management System (IDMMS) to provide the modeling and analysis capability required to understand the TWRS system behavior in terms of the identified TWRS performance measures.

The IDMMS mission analysis found the existing methods for analyzing and modeling system cost, schedule, technical performance, environmental impact, and risk to public and worker health and safety are neither integrated nor adequate to support a large, complex program. The currently available analysis and modeling tools are comprised of both manual and automated data inputs, manipulations, and outputs. An assortment of unverified databases are currently in use, making these models, assumptions, input data, and results difficult to verify and validate. Because of this, the results produced by these models are not accepted by the customer, U.S. Department of Energy and other stakeholders (Westinghouse Hanford Company [WHC], Pacific Northwest Laboratories [PNL], Washington State Department of Ecology [Ecology], U.S. Environmentai 'Protection Agency [EPA], etc.). Thus, building consensus, making decisions, and implementing the TWRS mission becomes very difficult.

Results from the IDMMS mission analys is concluded that an integrated computer simulation and information system is required to analyze and model TWRS cost, schedule, technical performance, environmental impact, and public and worker health and safety in an efficient, consistent, repeatable, verified, and validated manner. WHC has contracted Stone and Webster Advanced Systems Development Services, Inc. (SWASDS) to develop a data integration software system (TWRSview) to be used within the IDMMS. 
WHC-SD-WM-SFR-009 REV 0

\begin{tabular}{|c|c|c|c|c|c|c|c|c|c|c|c|c|c|c|c|}
\hline$\stackrel{8}{8}$ & & & 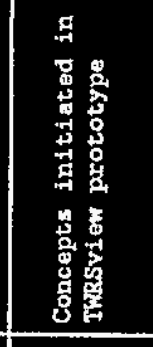 & & & 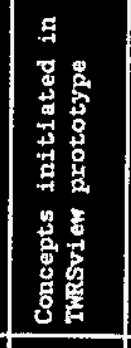 & & 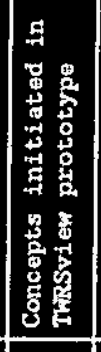 & 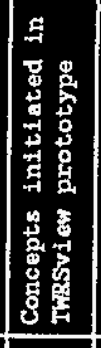 & 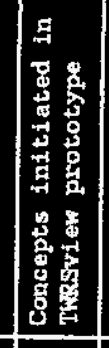 & 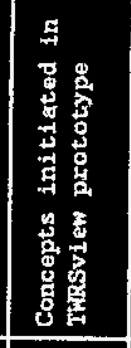 & 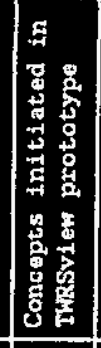 & 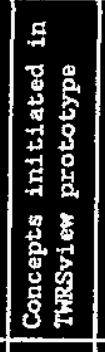 & 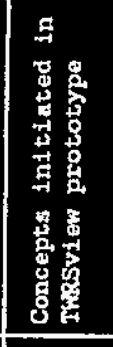 & 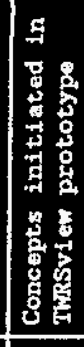 \\
\hline 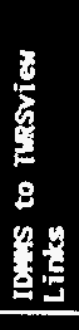 & & & & 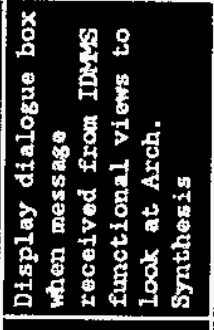 & & & 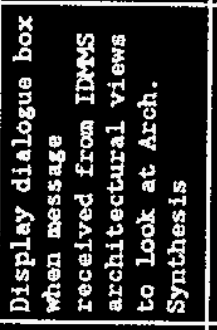 & & & & & & & & \\
\hline 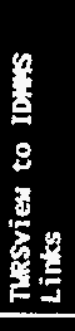 & & & & 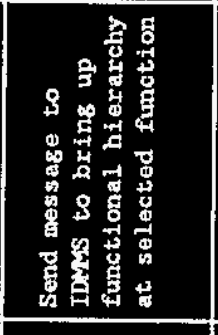 & & & 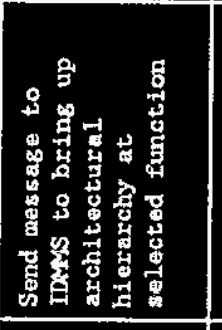 & & & & & & & & \\
\hline $\begin{array}{l}\text { 8. } \\
8 \\
8\end{array}$ & & & 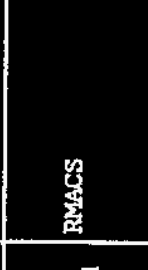 & 总 & & 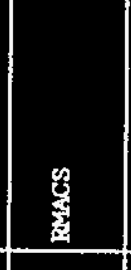 & 照 & & 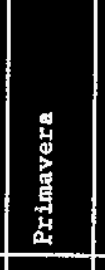 & 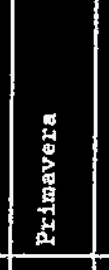 & 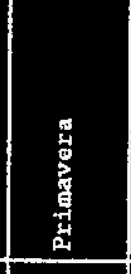 & 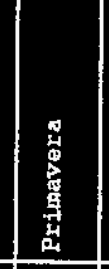 & 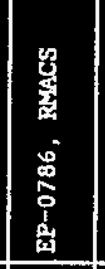 & 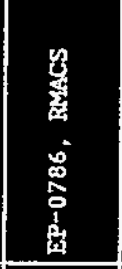 & 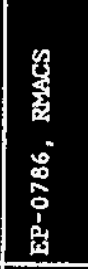 \\
\hline 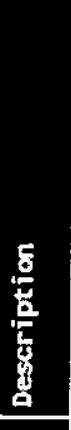 & 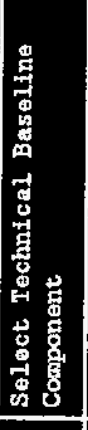 & & 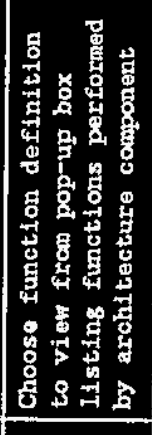 & 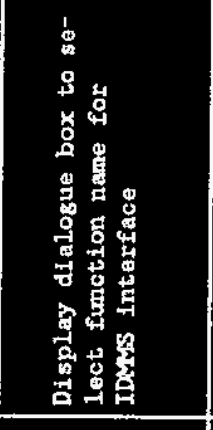 & & 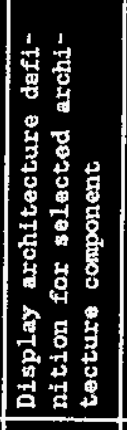 & & & 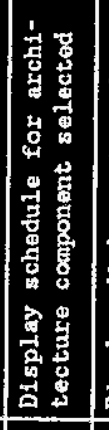 & 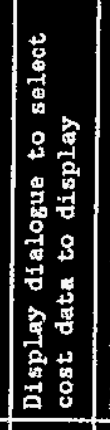 & 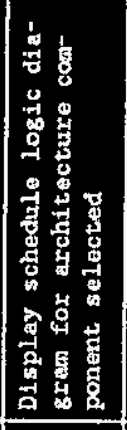 & 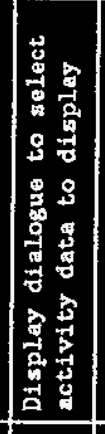 & 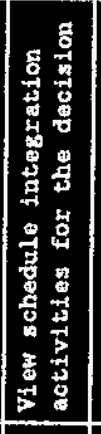 & 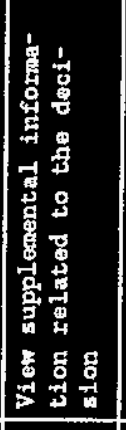 & 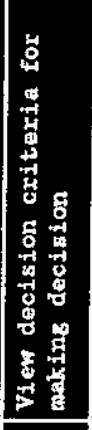 \\
\hline$\frac{8}{8}$ & $\begin{array}{l}\text { d] } \\
\text { d }\end{array}$ & & 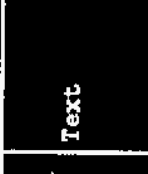 & 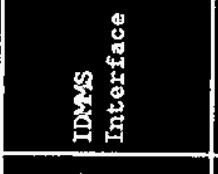 & & 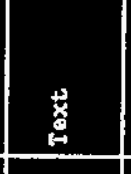 & 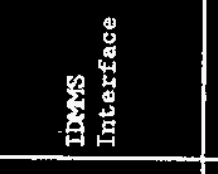 & & 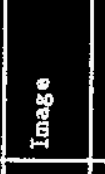 & 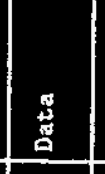 & 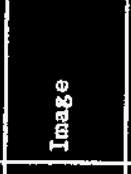 & 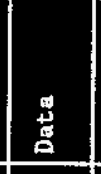 & 蔒 & 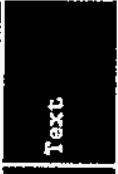 & 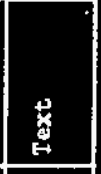 \\
\hline 莺 & 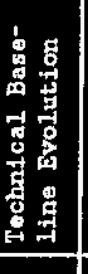 & 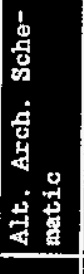 & 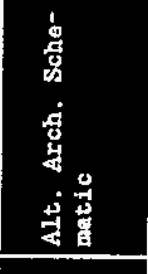 & 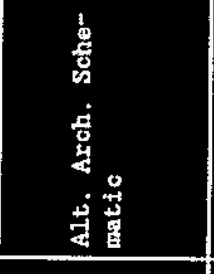 & 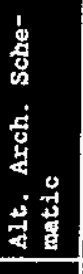 & 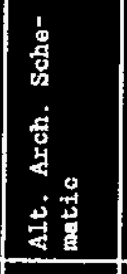 & 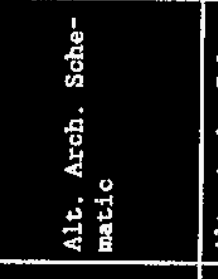 & 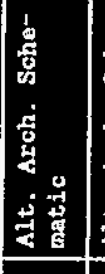 & 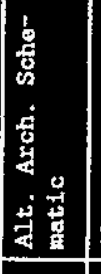 & 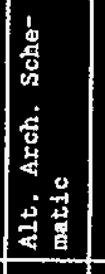 & 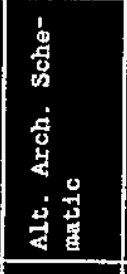 & 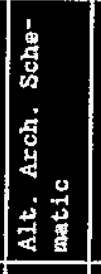 & 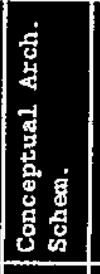 & 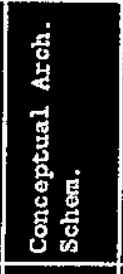 & 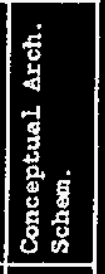 \\
\hline 9 & & 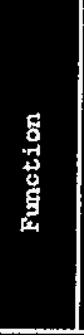 & 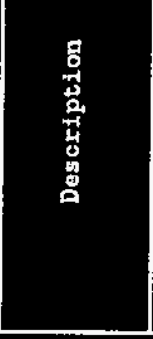 & 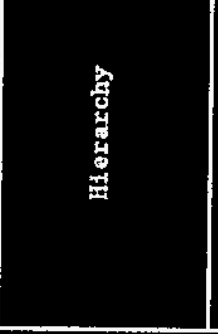 & 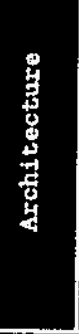 & 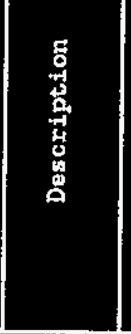 & 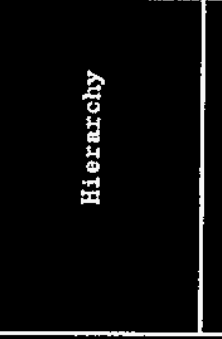 & 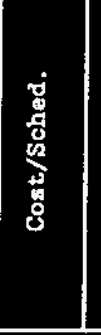 & 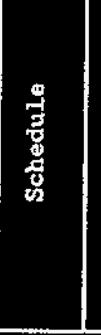 & 落 & 苛 & 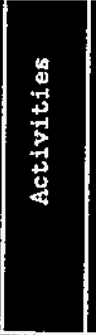 & 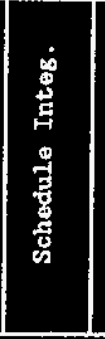 & 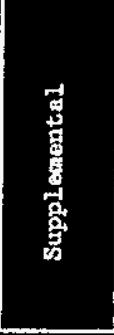 & 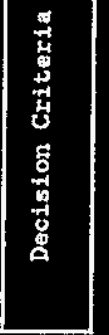 \\
\hline
\end{tabular}




\subsection{PURPOSE}

The purpose of this document is to define the essential requirements of the TWRSview software. This Software Requirements Specification (SRS) provides to the TWRSview developers a concise definition of the system software requirements. By emphasizing functions to be performed, rather than system architecture, the SRS will not be restrictive and will allow maximum flexibility during system design.

Contents of this guideline follows the guidance contained in WHC-CM-3-10, Software Management Practices.

\subsection{SCOPE}

The scope of the TWRSview project is to provide a software system that will interface with IDMMS to aid in integrating data related to the TWRS technical baseline. The delivered software system shall schematically model the conceptual TWRS architecture. The software system shall integrate TWRS program data by accessing the data from. its storage location(s) and associating the data to the modeled components of the TWRS architecture. The integrated information shall be accessible through a graphical user interface (GUI) utilizing mouse point and click functionality.

\subsection{OVERVIEW}

TWRS Technical Integration has felt for some time that the need for an application such as TWRSview is necessary. To confirm or negate this feeling, in January through March of 1995, contractors working for TWRS Technical Integration interviewed select systems analysts, TWRS Engineering Organization modelers and senior management. The purpose of these interviews were to derive requirements for managing information and implications for Technical Integration tools. Many interviewees felt that they have an enormous amount of data but no useable information. Meaning that the data is not summarized, organized or made easily available in a usable fashion. TWRSview is being developed to integrate and present the data to the Program in a meaningfui context to support the technical baseline integration efforts.

TWRSview is an expansion of the concept developed and known as TANKview. TANKview was a small scale demonstration model used for Tank Farm upgrades. TANKview did not evolve to a production application.

TWRS Technical Integration has engaged the SWASDS to create a prototype application of TWRSview. The initial prototype was delivered September 25, 1995 and installed on a Technical Integration general purpose server for evaluation.

Prototyping is being used as a tool for requirements gathering. TWRS Technical Integration has contracted with SWASDS for Fiscal Year 1996 to build on the prototype with various functions that will be described in the functional requirements section. 
WHC-SD-WM-SFR-009 REV 0

\begin{tabular}{|c|c|c|c|c|c|c|c|c|c|c|c|c|c|c|c|}
\hline$\stackrel{8}{\mathbb{H}}$ & & 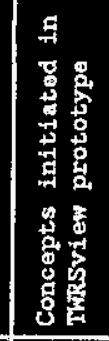 & 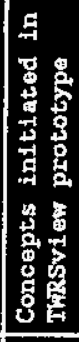 & 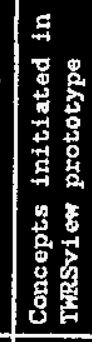 & 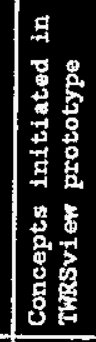 & 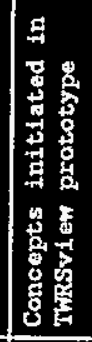 & 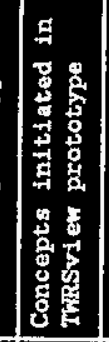 & & 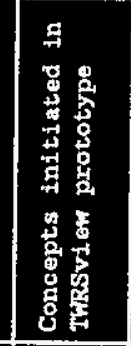 & 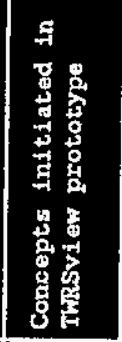 & 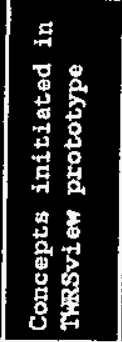 & 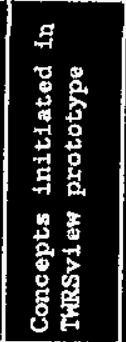 & 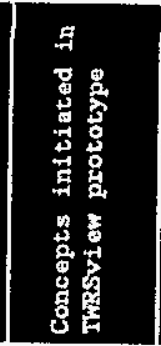 & 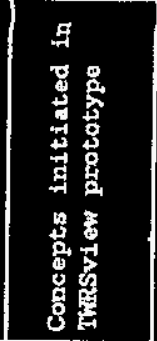 & 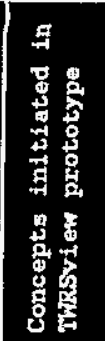 \\
\hline 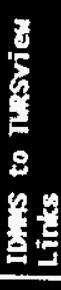 & & & & & & & & & & & & & & & \\
\hline 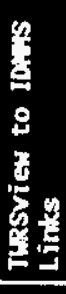 & & & & & & & & & & & & & & & \\
\hline $\begin{array}{l}8 \\
\frac{8}{8}\end{array}$ & & 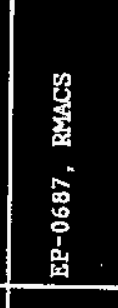 & 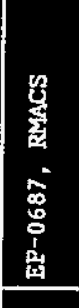 & 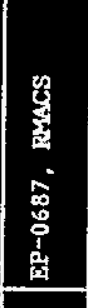 & 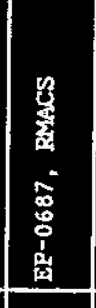 & 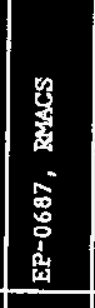 & 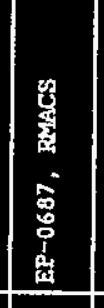 & 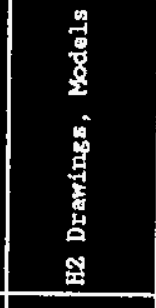 & 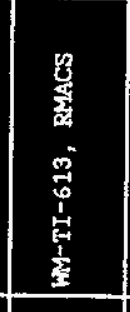 & 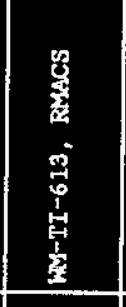 & 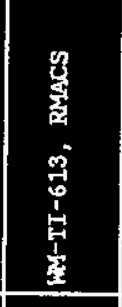 & 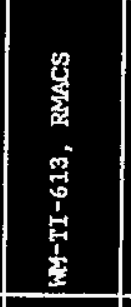 & 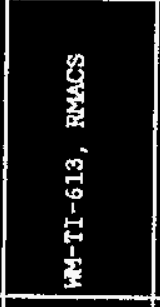 & 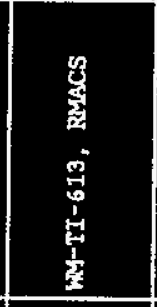 & 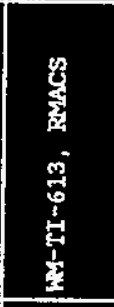 \\
\hline 点 & 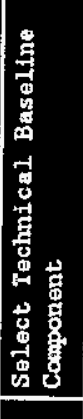 & 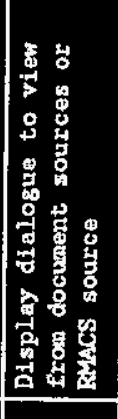 & 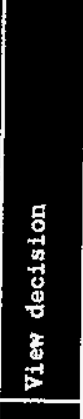 & 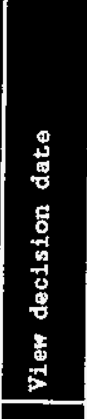 & 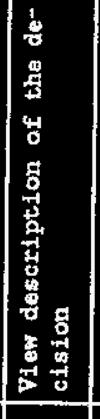 & 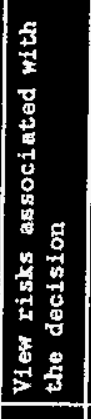 & 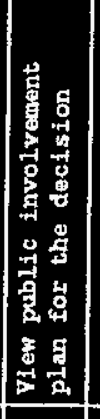 & 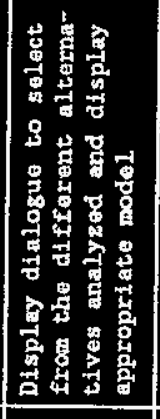 & 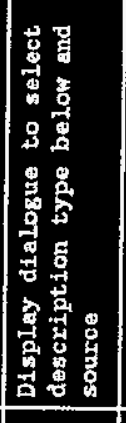 & 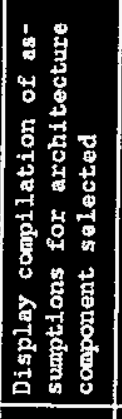 & 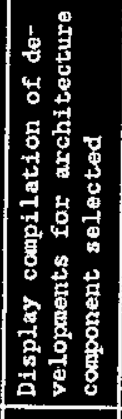 & 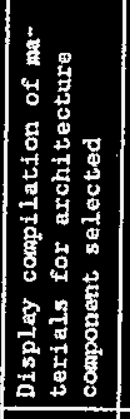 & 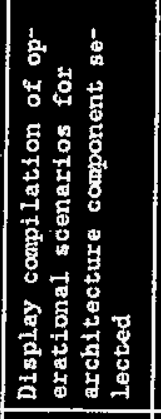 & 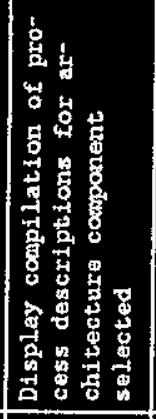 & 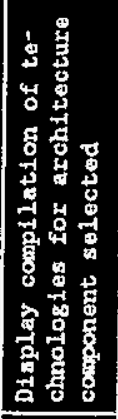 \\
\hline$E$ & $\begin{array}{l}\overrightarrow{0} \\
\frac{0}{8} \\
\end{array}$ & 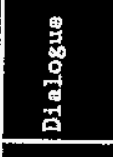 & 晜 & 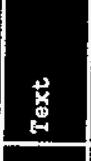 & 㽞 & \begin{tabular}{|l}
$\overrightarrow{\mathrm{*}}$ \\
\end{tabular} & 若 & 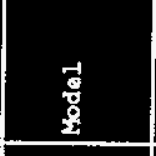 & 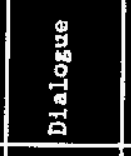 & 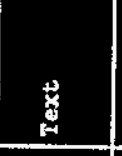 & 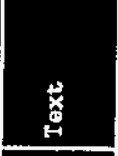 & 蒡 & 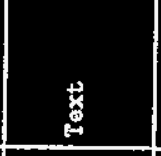 & 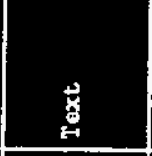 & 莒 \\
\hline 零 & 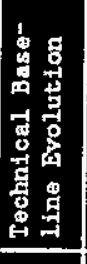 & 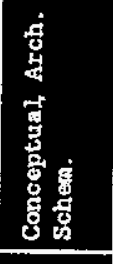 & 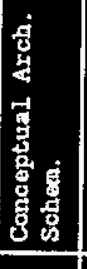 & 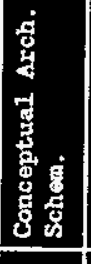 & 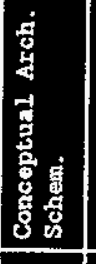 & 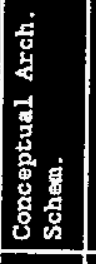 & 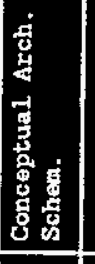 & 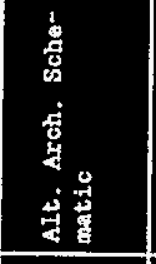 & 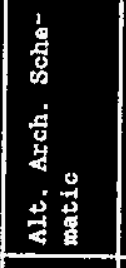 & 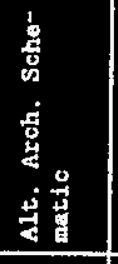 & 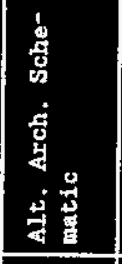 & 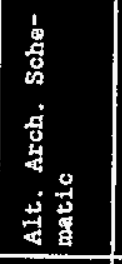 & 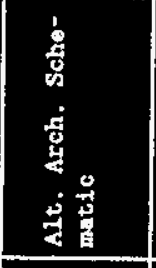 & 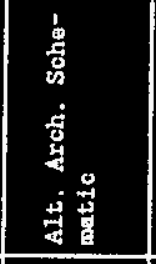 & 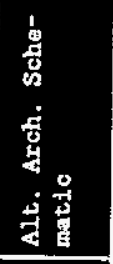 \\
\hline & & 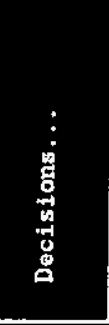 & 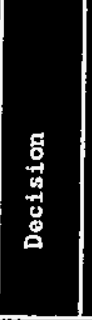 & 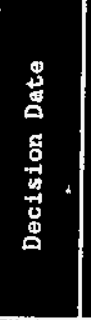 & 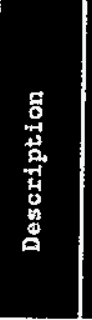 & $\frac{0}{0}$ & 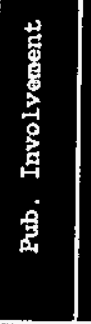 & 离 & 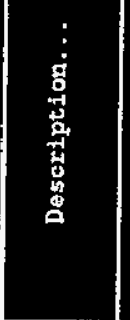 & 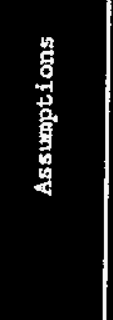 & 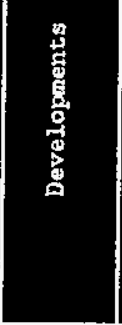 & 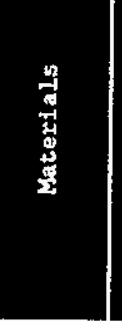 & 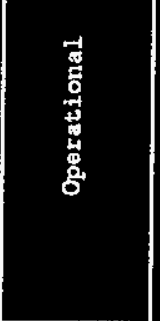 & 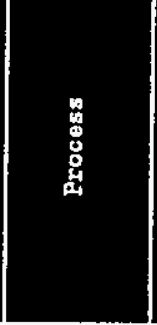 & 递 \\
\hline
\end{tabular}




\subsection{GENERAL DESCRIPTION}

This section describes the general factors that affect the requirements specification for TWRSview.

\subsection{PRODUCT PERSPECTIVE}

TWRSView is built on the philosophy of providing information to management and the individuals who use technical integration data daily. The intent is to get data from the various data sources and present it to management in a meaningful context to enable management to understand the integration of the data associated with the technical baseline. In this manner. TWRSview will present information to management so they may begin to make decisions and start driving the work needed to produce the type of information they require to perform their work. With this philosophy in mind, SWASDS developed the menu structure for TWRSview to present a story line to management. TWRSview is meant to be a query system not a processing applica-
tion.

The software system, though developed specifically for the TWRS Program, will be generic enough to be applied toward data integration for the whole Hanford Site cleanup program.

TWRSview is to be accessible from IDMMS. IDMMS provides system engineers with a set of computer-based tools that can be used to produce consistent analytical results in support of TWRS decisions. The primary building blocks of IDMMS are simulation tools. These tools permit modeling of the tank waste through retrieval, characterization, treatment and final disposal. Simulation models range from generic to very detafled. The key to IDMMS is integration of existing and yet-to-be-developed tools and data. IDMMS is currently being developed internal to WHC by TWRS Technical Integration.

\subsection{PRODUCT FUNCTIONS}

TWRSview will be a multi-phased project, as described below.

The first phase, a prototype based on the physical and technical data, existing site conditions, clean-up strategies and baseline programs has been partially accomplished. Future deliverables will incorporate the Technical Integration Management Process and will be delivered in several phases. The future phases are intended to build on the TWRSview prototype by providing integration of information through all aspects of the system engineering process in developing the technical basel ine. Technical basel ine development includes:

- Formation of the mission analysis.

- System functions and requirements synthesis.

- System architecture synthesis.

- System trade study analysis.

- System testing and verification.

- Program schedule and cost definition. 


\begin{tabular}{|c|c|c|c|c|c|c|c|c|c|c|}
\hline 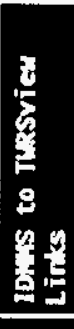 & & 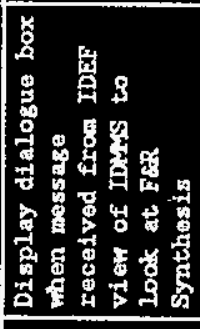 & 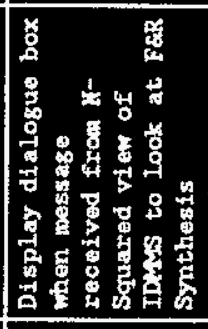 & 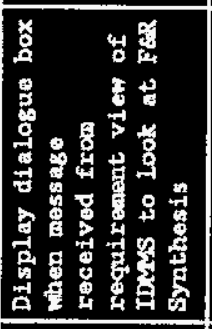 & 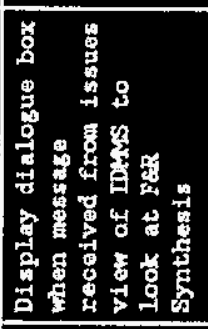 & 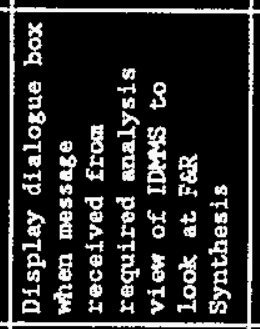 & & & & \\
\hline 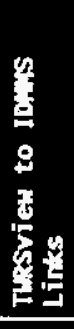 & & 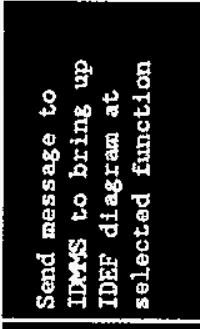 & 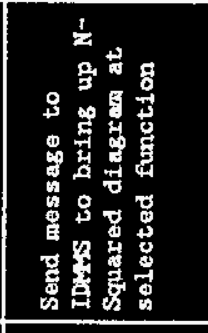 & 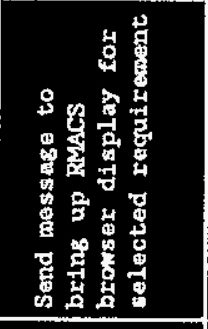 & 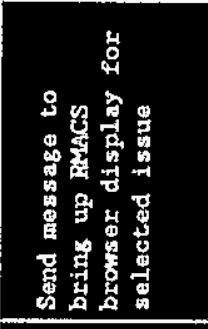 & 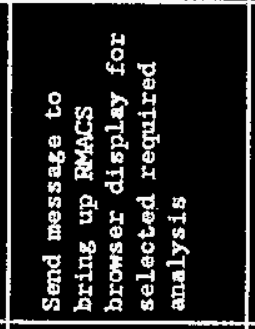 & & & & \\
\hline $\begin{array}{l}0.0 \\
8 \\
8 \\
8 \\
\end{array}$ & & 留 & 㷳 & 曾 & 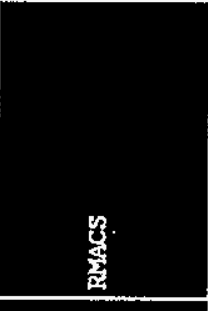 & 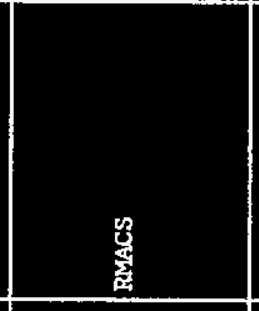 & & & 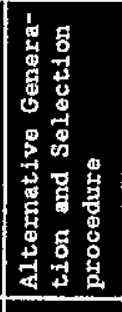 & 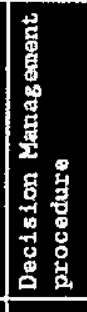 \\
\hline 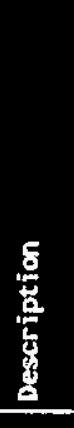 & 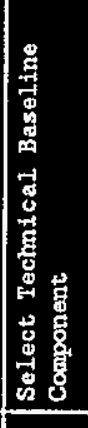 & 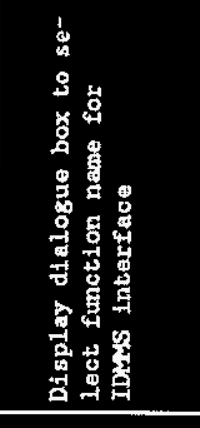 & 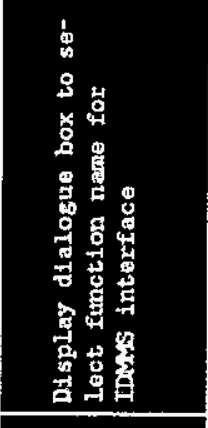 & 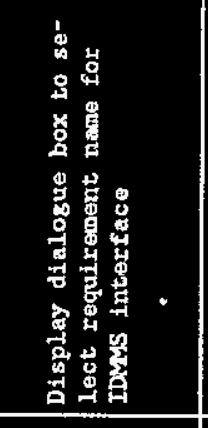 & 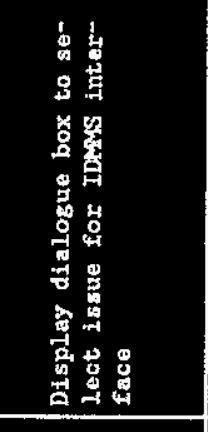 & 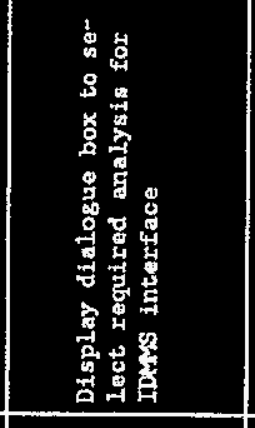 & 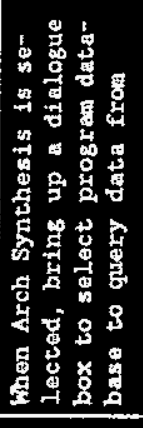 & & 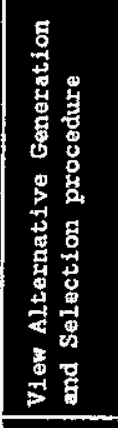 & 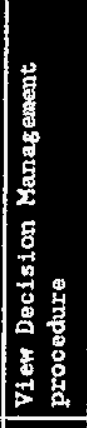 \\
\hline$\frac{5}{8}$ & \begin{tabular}{|l}
$\overrightarrow{0}$ \\
总 \\
\end{tabular} & 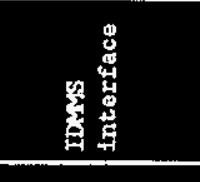 & 噌 & 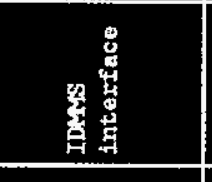 & 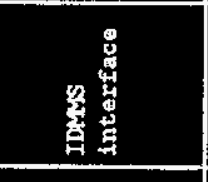 & 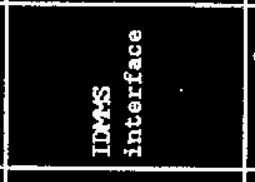 & $\begin{array}{l}\overrightarrow{\mathrm{g}} \\
\text { g. } \\
\end{array}$ & & 惹 & 总 \\
\hline 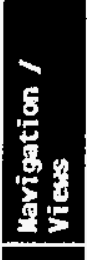 & 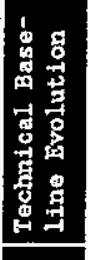 & 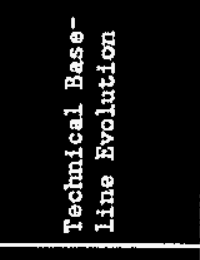 & 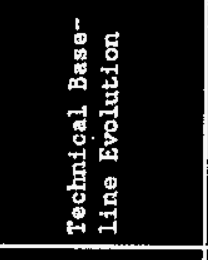 & 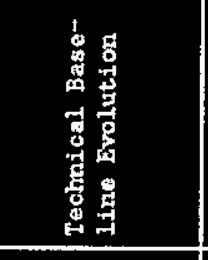 & 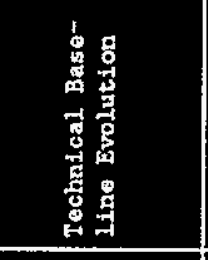 & 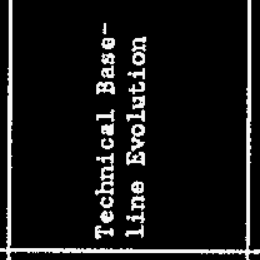 & 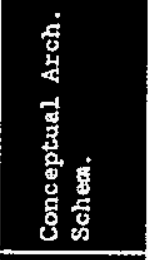 & 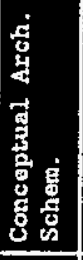 & 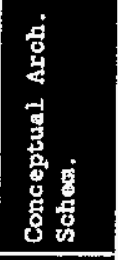 & 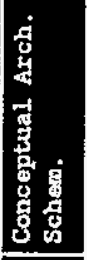 \\
\hline 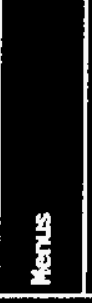 & & 晉 & 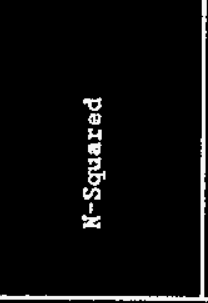 & 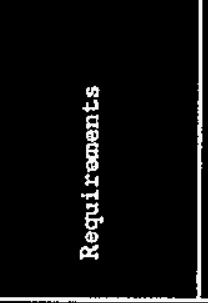 & 噌 & 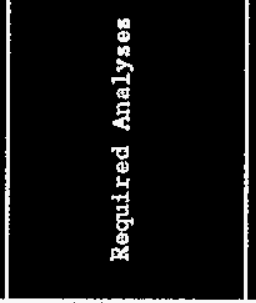 & 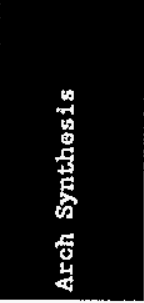 & 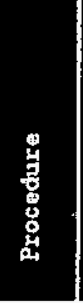 & 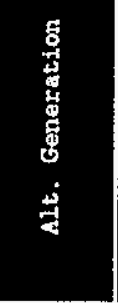 & 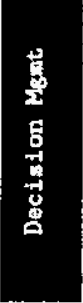 \\
\hline
\end{tabular}


Integration of the technical baseline developments include:

- Understanding of the TWRS behavior in terms of technology performance, cost, and schedule parameters.

- Assessing tradeoffs in the parameters.

- Communication of TWRS program information.

r TWRS baseline system verification.

\subsection{USER CHARACTERISTICS}

Al1 users will require basic computer skills and knowledge of operating in a windows environment.

All users will receive basic TWRSview training before being provided access to any portion of the system. Primary users will be program managers that can benefit from the type of information contained in TWRSview. Engineers will need to be knowledgable of TWRSView, as they are the source of much of the information to be supplied.

\subsection{GENERAL CONSTRAINTS}

TWRS Technical Integration has determined that TWRSview will be an approval designator $Q$.

\subsection{ASSUNPTIONS AND DEPENDENCIES}

SWASDS must be available to supply technical support for the duration of development and initial implementation. TWRS Technical Integration will assume responsibility for the software and maintenance after implementation. In the event that SWASDS is unable to provide technical support, other resources will be identified and pursued to complete the task.

STONEview ${ }^{1}$ software 1 icenses must be obtained. STONEview is a product developed and owned by the SWASDS. SWASDS will supply an initial set of individual user licenses.

A file server must be available and compatible. The prototype of TWRSview will be installed on a general purpose Hanford Local Area Network (HLAN) server. Final implementation will need to be on an application file server, al though one has not been identified.

The data supporting TWRSview will be growing as more functions and requirements are defined for individual TWRS program elements. Therefore, it is important for configuration management of data source information to occur.

${ }^{1}$ STONEview is a trademark of Stone and Webster Advanced Systems Development Services, Inc. 


\begin{tabular}{|c|c|c|c|c|c|c|c|}
\hline Ferus & $\begin{array}{l}\text { Mavigation / } \\
\text { Vieus }\end{array}$ & Form & Description & Sources & $\begin{array}{l}\text { Thasvien to IDws } \\
\text { Links }\end{array}$ & $\begin{array}{l}\text { IDins to Tussien } \\
\text { Links }\end{array}$ & Comments \\
\hline & $\begin{array}{l}\text { Teahnical Base- } \\
\text { line Evolution }\end{array}$ & Kode1 & $\begin{array}{l}\text { Select Technical Baseline } \\
\text { Component }\end{array}$ & & & & \\
\hline Cost Estimates & Scope Diegraa & Text & $\begin{array}{l}\text { Viow cost estimatos of so- } \\
\text { lected strategy }\end{array}$ & $\begin{array}{l}\text { risk based approach } \\
\text { to Hanford site } \\
\text { cleanug document }\end{array}$ & & & $\begin{array}{l}\text { Concopts initiated In } \\
\text { Twisvien prototype }\end{array}$ \\
\hline Interfaces & $\begin{array}{l}\text { Mission Analysis } \\
\text { Schematic }\end{array}$ & & & & & & \\
\hline Guidelines & $\begin{array}{l}\text { Hission Analysis } \\
\text { Schematic }\end{array}$ & Text & $\begin{array}{l}\text { Vtew guidelines to identify } \\
\text { system interfaces }\end{array}$ & & & & \\
\hline Report & $\begin{array}{l}\text { Mission Analysis } \\
\text { Schematic }\end{array}$ & Text & $\begin{array}{l}\text { Choose text of system in- } \\
\text { terface topics to viem }\end{array}$ & $\begin{array}{l}\text { mission analysis } \\
\text { reports }\end{array}$ & & & \\
\hline Miss. Level Requnts & $\begin{array}{l}\text { Mission Analysis } \\
\text { Schematic }\end{array}$ & & & & & & \\
\hline Guidelines & $\begin{array}{l}\text { Misston Analysis } \\
\text { Schematic }\end{array}$ & Text & $\begin{array}{l}\text { View guidelines to identify } \\
\text { mission level requitrements }\end{array}$ & & & & \\
\hline Report & $\begin{array}{l}\text { Hission Analysis } \\
\text { Schematic }\end{array}$ & Text & $\begin{array}{l}\text { Choose text of mission lev- } \\
\text { el requirement topics to } \\
\text { view }\end{array}$ & $\begin{array}{l}\text { mission analysis } \\
\text { reports }\end{array}$ & & & \\
\hline System Lifo Cyclo & $\begin{array}{l}\text { Mission Analysis } \\
\text { Schematic }\end{array}$ & & & & & & \\
\hline Guidelines & $\begin{array}{l}\text { Mission Analysis } \\
\text { Schematic }\end{array}$ & Text & $\begin{array}{l}\text { View guidelines to eapture } \\
\text { system life cycle }\end{array}$ & & & & \\
\hline Report & $\begin{array}{l}\text { Mission Analysis } \\
\text { Schematic }\end{array}$ & Text & $\begin{array}{l}\text { Choose text of systen lifa } \\
\text { cycle topics to yiem }\end{array}$ & $\begin{array}{l}\text { mission analysis } \\
\text { reports }\end{array}$ & & & \\
\hline FaR Synthesis & $\begin{array}{l}\text { Technical Base- } \\
\text { line Evolution }\end{array}$ & Kodel & $\begin{array}{l}\text { When FER Synthesis is se- } \\
\text { lected, bring up a dialogue } \\
\text { box to select program data- } \\
\text { base to query data from }\end{array}$ & & & & \\
\hline Frocedure & $\begin{array}{l}\text { Technical Bnse- } \\
\text { line Erolution }\end{array}$ & Text & $\begin{array}{l}\text { View Functions and Require- } \\
\text { ments Analysis and Alloca- } \\
\text { tion procedure }\end{array}$ & $\begin{array}{l}\text { Functions and Re- } \\
\text { quirenents Analysis } \\
\text { and Allocation pro- } \\
\text { codure }\end{array}$ & & & \\
\hline Functions & $\begin{array}{l}\text { Technical Base- } \\
\text { line Evolution }\end{array}$ & & & & & & \\
\hline Hierarchy & $\begin{array}{l}\text { Technical Base- } \\
\text { Ifne Evolution }\end{array}$ & $\begin{array}{l}\text { IDEas } \\
\text { interface }\end{array}$ & $\begin{array}{l}\text { Display dialogue box to se- } \\
\text { lect function name for } \\
\text { IDhws interface }\end{array}$ & IDtars & $\begin{array}{l}\text { Send message to } \\
\text { IDws to bring up } \\
\text { functional hieraxchy } \\
\text { yier at selected } \\
\text { function }\end{array}$ & $\begin{array}{l}\text { Display dialogue box } \\
\text { when message } \\
\text { received fron } \\
\text { function hieraxchy } \\
\text { view of IDiss to } \\
\text { look at Far } \\
\text { Synthesis }\end{array}$ & \\
\hline
\end{tabular}


Boeing's Information Systems Definition (ISD) work effort intends to help support this long range dependency.

System owners of the data sources must also buy-in and agree to support the interfacing and/or supplying of the information. If the buy-in and support from systems owners is not accomplished then the integrity of the data will be questionable.

\subsection{SPECIFIC REQUIREMENTS}

The TWRSview product is a view only application. It is intended to be a tool to provide program managers with enough information to begin making decisions based on mission needs.

\subsection{FUNCTIONAL REQUIRENENTS}

This portion of the SRS describes the functional requirements for TWRSview. Sections are logically separated based on the functions to be performed to show integration in each part of the technical baseline development. Appendix A provides guidelines for what to include in the menu structures for TWRSview to satisfy the functional requirements identified below.

Inputs accessed by TWRSview will be addressed via tables, describing the data source, methods anticipated of populating the database for implementation and future plans to access the data. Outputs are addressed as a separate section due to TWRSview being a view only application.

\subsubsection{Mission Analysis Formulation}

SWASBS will create models based on information supplied from TWRS Technical Integration. These models will be used to navigate through information related to a system's mission añalysis. Functions performed from the mission analysis models include:

- display the mission analysis procedure

- view guidelines for preparing specific portions of the mission analys is

- view the specific definition for each portion of the mission analysis

- display images of the system boundary diagrams for systems being analyzed

- query and display appropriate text and/or data from mission analysis for key mission analys is components (i.e., mission definition, initial unacceptable conditions, acceptable end states, system 
WHC-SD-WM-SFR-009 REV 0

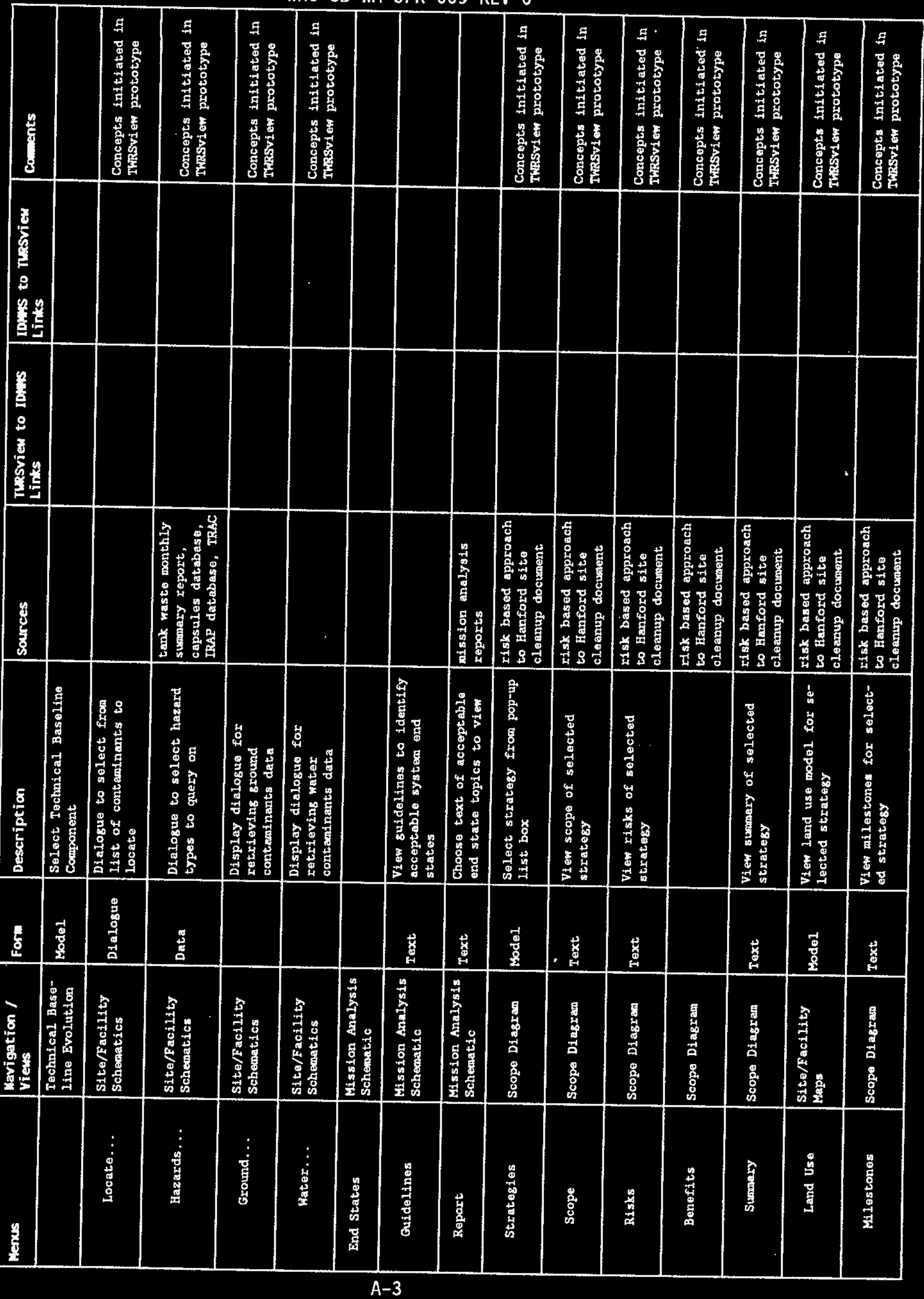


boundaries and external interfaces, mission level requirements, and
system life cycle)

- provide capability to add results from new mission analyses to the developed query structure

- provide capability to readily update mission analys is models and maintain database links.

\subsubsection{System Functions and Requirements Synthesis}

Systems functions and requirements synthesis is performed using the TWRS Technical Integration Requirements Management and Assured Compl fance System (RMACS). The software system shall interface with one of the RMACS tools (a requirements allocation to the functions ion system) to graphically depict this task TWRSview should:

- provide communication Tinks between TWRSview and IDMMS

- provide a database structure that can be updated to provide additional relationships between IDMMS views and TWRSview models which is used to produce the communication links

- provide menu functions to perform the following:

- display the Functions and Requirements Analys is and AJlocation
procedure

- display results from functional analysis (i.e., function decomposition and function definition). This will primarily be accomplished through communication links with IDMMS

- display results from requirements analysis showing requirements development, requirements al location, and requirements validation. Requirements development and allocation comes from RMACS and IDMMS communication links. Requirements validation is provided by results from parametric studies, analysis, or
simulation.

\subsubsection{System Architecture Synthes is}

SWASDS wi17 create models of the system architectures defined by TWRS Technical Integration that wi11 carry out the synthesized functions. The system architectures will be provided in the form of Computer-aided Design (CAD) generated flowsheets, drawings, and graphics in multiple formats. The models created with in the software system shall provide traceability of functions and requirements allocation to architecture components. Traceability of functions and requirements allocation shall be accomplished through mouse point and click functions on the modeled architecture
components. 


\begin{tabular}{|c|c|c|c|c|c|c|c|c|c|c|c|c|c|c|c|c|c|}
\hline$\frac{8}{8}$ & & & & & & & & & & & 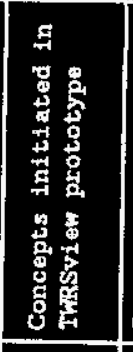 & 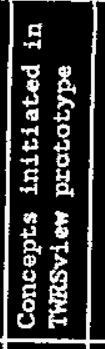 & 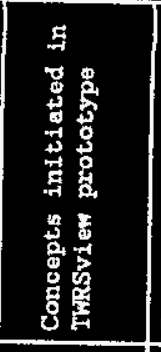 & 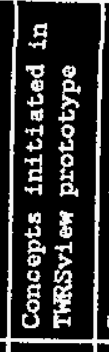 & 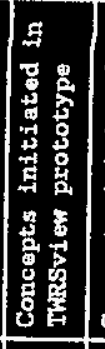 & 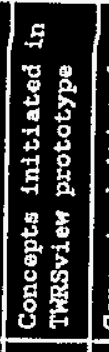 & 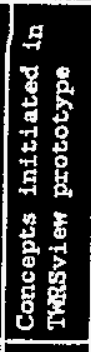 \\
\hline 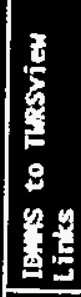 & & & & & & & & & & & & & & & & & \\
\hline 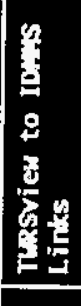 & & & & & & & & & & & & & & & & & \\
\hline $\begin{array}{l}8 \\
8 \\
8 \\
8 \\
\end{array}$ & & & 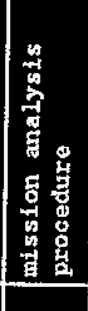 & & & 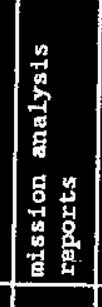 & 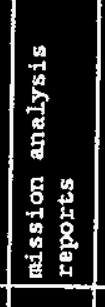 & & & 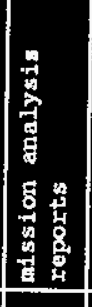 & & & 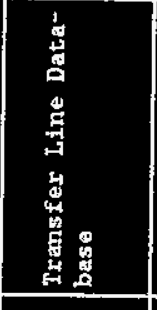 & & & & \\
\hline 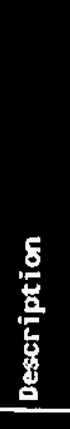 & 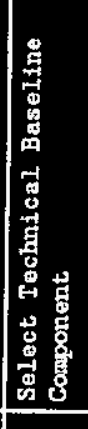 & 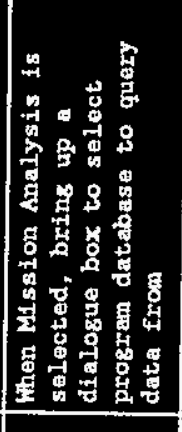 & 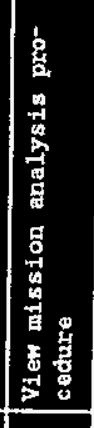 & & 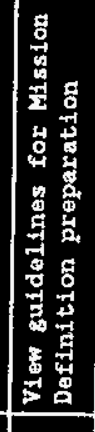 & 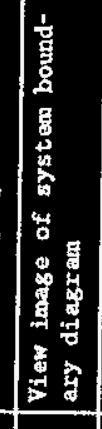 & 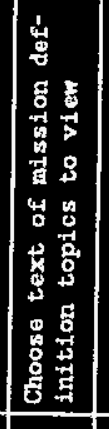 & & 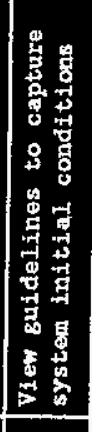 & 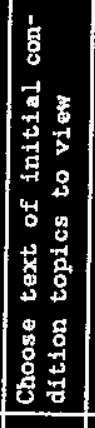 & 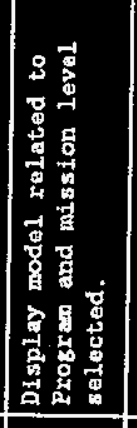 & & 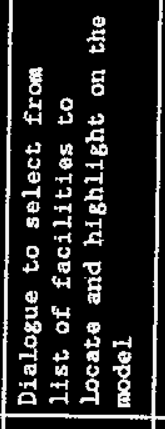 & 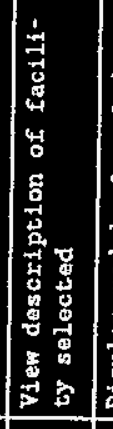 & 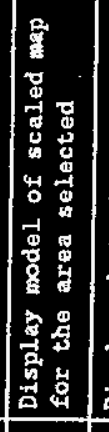 & 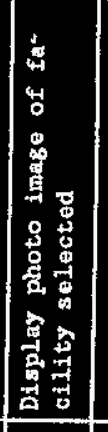 & \\
\hline 은 & $\begin{array}{l}-1 \\
8 \\
0 \\
\end{array}$ & $\begin{array}{l}\overrightarrow{0} \\
5 \\
0 \\
\end{array}$ & 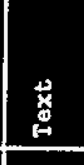 & & 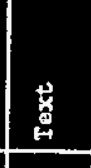 & 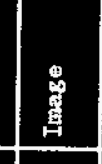 & 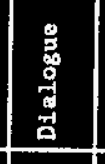 & & 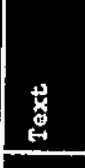 & 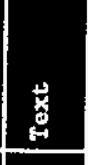 & $\begin{array}{l}\overrightarrow{0} \\
8 \\
8\end{array}$ & & 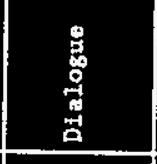 & 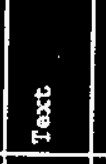 & $\begin{array}{l}\overrightarrow{0} \\
\stackrel{8}{8} \\
\end{array}$ & $\begin{array}{r}8 \\
8 \\
8 \\
5 \\
\end{array}$ & \\
\hline 点 & 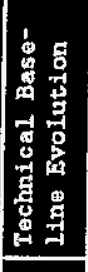 & 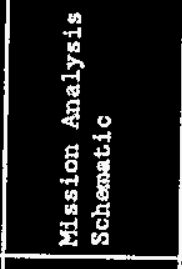 & 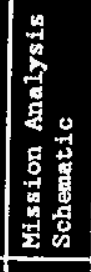 & 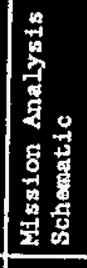 & 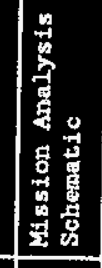 & 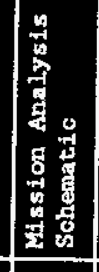 & 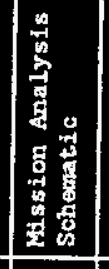 & 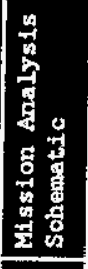 & 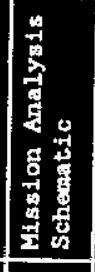 & 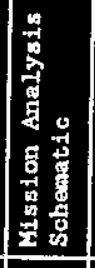 & 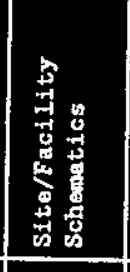 & 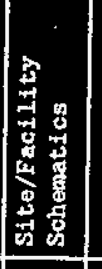 & 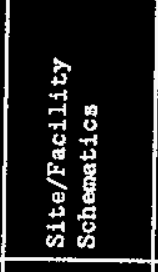 & 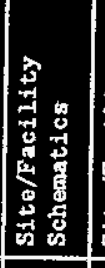 & 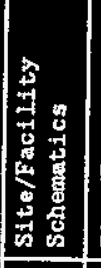 & 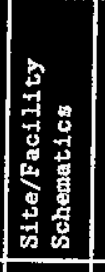 & 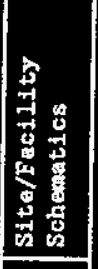 \\
\hline$\frac{2}{2}$ & & 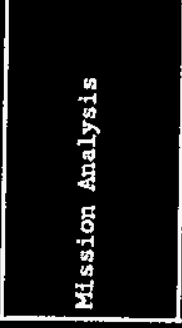 & 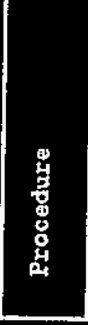 & 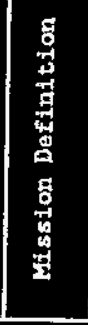 & 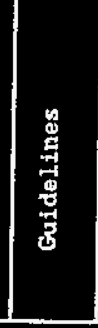 & 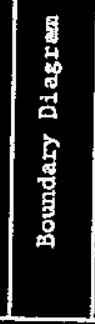 & 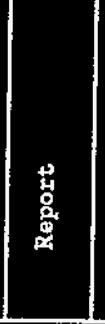 & 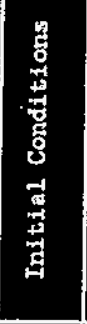 & 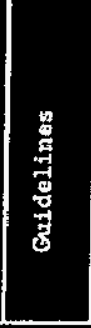 & 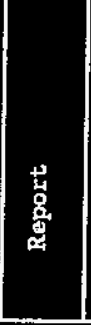 & 总 & 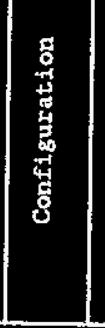 & 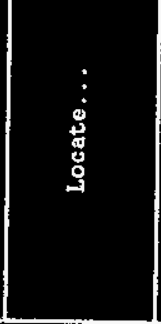 & 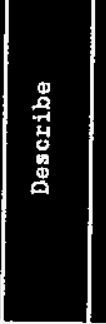 & 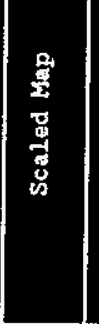 & 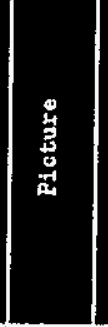 & 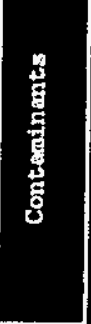 \\
\hline
\end{tabular}


Specific functions to be performed include:

- display alternative generation and selection procedure

- display decision management procedure

- display decisions required for the program resulting from the functional analysis

- display alternatives generated to satisfy the functions, requirements, and performance measures. Alternatives may be displayed in a number of ways including textual, image, or CAD drawings of conceptual system configuration

- display decision criteria for selecting alternative

- provide capability to add additional decisions and alternative architecture selections into the defined database structures for the software system

- provide capability to update architecture models and maintain database links.

\subsubsection{System Trade Studies Analysis}

The software system shall provide traceability of trade study analyses to the system architecture. Views of alternative system architectures evaluated in the trade studies shall be provided. The software system shall access trade study analyses data from the database sources and integrate the data through mouse point and click functionality in the system architecture models. System trade studies. include risk analysis, decision analysis, cost and schedule analysis, and process simulation.

Trade studies encompass results from multiple analysis. Therefore, the software system structure shall be designed and constructed in such a manner to capture trade study data for a given decision statement in a consistent database structure such that results from new analysis for the trade study may be added without redesign or redevelopment of the sof tware. The software system shall have the capabilities to select from the multiple trade study analyses to assess the results from a particular analysis or compare results between two or more analyses.

Specific functions provided by the software system to show traceability of trade study analyses include:

- query capability to select among the various analyses for a particular decision

- query and display results from analysis

- run trade analysis models that have been set up for access to users 
WHC-SD-WM-SFR-009 REV 0

APPENDIX A

A-1 
- provide capability to add additional trade study analyses into the defined database structures for the software system

- provide capability to update trade study models and maintain database links.

\subsubsection{System Testing and Verification}

The software system shall integrate testing and verffication data for the system architecture to the system models. Traceability to system technical performance measures and verification data shall be provided. Specific functions provided by the software system to show traceability include:

- display technical performance measures for system being tested

- query and display testing and verification results

- provide capability to add additional testing and verification results into the defined database structures for the software system.

\subsubsection{Program Schedule and Cost Definition Section}

The software system shall provide traceability between the system technical baseline development and the program management baseline. The software system shall access the program basel ine schedule and cost database data. Traceability to the system technical baseline will be accomplished with mouse point and click functionality in the system architecture models. The software system shall also provide functionality to show effects to the program or technical baseline caused by changing program or technical bases.

\section{1 .7 Inputs}

Below are the known sources of inputs for the prototype of TWRSview. This is not a complete list and will be expanded to include other sources prior to implementation. The first column, data sources, is the known source of information. The second column, implementation, is the anticipated method of populating the database for initial implementation. The third column, future, is the anticipated method of accessing the data in the future.

\begin{tabular}{|l|l|l||}
\hline \multicolumn{1}{|c|}{ Data Source } & \multicolumn{1}{c|}{ Implementation } & \multicolumn{1}{c|}{ Future } \\
\hline \hline $\begin{array}{l}\text { "Waste Tank Summary } \\
\text { Report" }\end{array}$ & $\begin{array}{l}\text { spreadsheet format, } \\
\text { manipulated and uploaded }\end{array}$ & electronic access \\
\hline
\end{tabular}


WHC-SD-WM-SFR-009 REV 0

This page intentionally left blank. 


\begin{tabular}{|c|c|c|}
\hline Data Source & Implementation & Future \\
\hline CAPSULES Database & $\begin{array}{l}\text { updated quarterly } \\
\text { DBase copy to ThRSview } \\
\text { area }\end{array}$ & same \\
\hline Normalized TRAC & $\begin{array}{l}\text { spreadsheet format and im- } \\
\text { ported }\end{array}$ & $\begin{array}{l}\text { direct link with Tank } \\
\text { Characterization } \\
\text { Database }\end{array}$ \\
\hline $\begin{array}{l}\text { "Development of a Risk- } \\
\text { Based Approach to } \\
\text { Hanford Site Cleanup" } \\
\text { DRAFT }\end{array}$ & $\begin{array}{l}\text { WordPerfect }{ }^{2} \text { format } \\
\text { copy to TWRSview area }\end{array}$ & same \\
\hline ARENA models & ascii text and import & same. \\
\hline ASPEN models & ascif text and import & same \\
\hline $\begin{array}{l}\text { WHC-SD-WM-TI-613 } \\
\text { "TWRS Process } \\
\text { Flowsheet" }\end{array}$ & $\begin{array}{l}\text { WordPerfect format } \\
\text { copy to TWRSview area }\end{array}$ & SGML converted format \\
\hline $\begin{array}{l}\text { WHC-EP-0856 } \\
\text { "Tank Waste Remediation } \\
\text { System Operational } \\
\text { Scenario" }\end{array}$ & $\begin{array}{l}\text { WordPerfect format } \\
\text { periodic copy to TWRSview } \\
\text { area }\end{array}$ & same \\
\hline $\begin{array}{l}\text { RMACS } \\
\text { "Requirements Manage- } \\
\text { ment and Assured Com- } \\
\text { pliance System" }\end{array}$ & $\begin{array}{l}\text { direct7y access via } \\
\text { Microsoft Access }\end{array}$ & same \\
\hline $\begin{array}{l}\text { P3 } \\
\text { "TWRS program cost and } \\
\text { schedule information" }\end{array}$ & $\begin{array}{l}\text { spreadsheet format and } \\
\text { graphics, copy to TWRSview } \\
\text { area }\end{array}$ & Link into PMCS \\
\hline $\begin{array}{l}\text { OWVP } \\
\text { "Operationa] Waste Vol- } \\
\text { ume Projection" }\end{array}$ & $\begin{array}{l}\text { WordPerfect and graphics, } \\
\text { scanned image file loaded } \\
\text { to TWRSview area }\end{array}$ & $\begin{array}{l}\text { May be replaced and wiTl } \\
\text { evaluate direct Iink }\end{array}$ \\
\hline $\begin{array}{l}\text { Flowsheets } \\
\text { "CAD drawings" }\end{array}$ & copy to TWRSview area & $\begin{array}{l}\text { direct link if drawings } \\
\text { can be standardized }\end{array}$ \\
\hline $\begin{array}{l}\text { IRAP } \\
\text { "Integrated Risk } \\
\text { Assessment Program" }\end{array}$ & $\begin{array}{l}\text { Paradox } x^{3} \text { format } \\
\text { copied to TWRSview area }\end{array}$ & $\begin{array}{l}\text { direct link if firewall } \\
\text { issue can be overcome }\end{array}$ \\
\hline
\end{tabular}

'DBase is a trademark of Ashton-Tate.

${ }^{2}$ WordPerfect is a trademark of WordPerfect Corporation.

${ }^{3}$ Paradox is a trademark of Borland International. 
Access to the data on the file server will be password protected to guard against unauthorized access.

\subsection{REFERENCES}

Johnson, M. E., 1994, Tank Waste Remediation Systems Decision and Risk Assessment, WHC-EP-0786, Westinghouse Hanford Company, Rich Tand, Washington.

Johnson, M. E., 1995, Tank Waste Remediation System Operational Scenario, WHC-EP-0856, Westinghouse Hanford Company, Richland Washington.

Orme, R. M., 1995, TWRS Process Flowsheet, WHC-SD-WM-TI-613, REV 1, Hestinghouse Hanford Company, Richland, Washington.

WHC-CM-3-10, Software Practices, Westinghouse Hanford Company, Richland, Washington. 


\begin{tabular}{|l|l|l|}
\hline \multicolumn{1}{|c|}{ Data Source } & \multicolumn{1}{|c|}{ Implementation } & \multicolumn{1}{|c|}{ Future } \\
\hline $\begin{array}{l}\text { WHC-EP-0786 } \\
\text { Ristem Decision and }\end{array}$ & ascij text and import & $\begin{array}{l}\text { direct link by storing } \\
\text { in RMACS }\end{array}$ \\
\hline $\begin{array}{l}\text { KE/PT\&C } \\
\text { Excel }\end{array}$ & copy to TWRSview area & direct link \\
\hline
\end{tabular}

\subsubsection{Outputs}

Outputs to be provided are as follows:

- provide capability to print text file being displayed

- provide capability to print complete image file being displayed

- image viewing functionality shall include zoom, zoom area, refresh, and pan

- text viewer shall provide functionality to copy full text or selected text to the windows clipboard or into a text file that can be read by a word processor such as WordPerfect or Microsoft Word'.

- image viewer shall provide functionality for user to copy image file to user defined destination

- export results of queries to another file or print

- data source references will be identified either in data queries or results of data queries.

\subsection{EXTERNAL INTERFACE REQUIREMENTS}

\subsubsection{User Interfaces}

A graphical user interface will be used to allow users to view the information specified in the functional requirements section. The GUI will provide a means to access and view the information on a personal computer by using a mouse point and click function. The GUI shall provide hierarchial views of the physical components that make up the TWRS basel ine system. From each of these views, the user shall be able to access the TWRS program data identified in the functional requirements section associated with the system

The underlying data structure used by the GUI to show the information integration must be dynamic to allow changes for carrying out various "whatif" scenarios. TWRS Technical Integration source data may reside in multiple

'Microsoft Word is a trademark of Microsoft Corporation. 
1. Introduction

The introduction provides a general description of the software system. The purpose of the introduction is to provide users with an overview of the functions performed by the system and how the system operates.

2. Preliminary Design

This section lists the forms, libraries, and tables used in developing the software system.

3. Detail Design

This section of the SDD describes each form, method, and library used in the database administration section of the software system. The following items are suggested to describe each component:

Input/Output data elements

Local data elements

Error handiing

Logic flow

Local database structures

External database query design structure

Dialogue design structure

Data, text and graphic display structures

TWRSview instaliation scripts

- Integration of new data into the models (minor maintenance data changes, etc.)

4. References

\subsubsection{Training}

SWASDS shall provide two (2) days of training on SWASDS's delivered software system directly after each phase. This training shall be provided to TWRS Technical Integration's personnel at TWRS Technical Integration's work site.

Future training to users witl be provided by TWRS Technical Integration. TWRS Technical Integration will supply Points of Contact within their organization for question/answers pertaining to the use of TWRSview.

\subsubsection{Security and Privacy}

Distribution of access to the TWRSview application and the. number of users allowed will be controlled by TWRS Technical Integration. The data viewed via the application is not of a private nature. Therefore, there is not the need to have userid/password control beyond the HLAN signon. 
sources and on different computers. SWASDS's software system shall be able to connect to the individual data sources so that when changes are made by the data owner, the effects to the TWRS program can be displayed through the GUI.

\subsubsection{Hardware Interfaces}

The software system shall be deployed over HLAN. SWASDS witl provide support to access database, information and display information using the Hanford computer network.

SWASDS shall work with TWRS Technical Integration to develop installation scripts so that user's can install the software system on their PCs and set up file directory paths.

Subject to the security, copyright, and/or software 1 icense agreements, the TWRS Technical Integration will also provide HLAN environment and database connection information to include the following:

1. HLAN software and protocol

2. Database servers:
a. Hardware
b. Operating System
c. Database software and version
d. Database Dynamic Link Libraries
e. Database address for each pertinent data

3. File Servers
a. File address for each pertinent data file

The software system for modeling the TWRS baseline system shall be capable of running under Microsoft Windows on IBM compat ible personal computers.

\subsubsection{Software Interfaces}

The software system shall access information not residing within the 3-D modeling environment (e.g., RMACS data, tank waste inventory data, etc.).

SWASDS's software system shall be compatible for executing with in the IDMMS computing environment developed by TWRS Technical Integration. Database structures developed by SWASDS to complete this task shall be commensurate with the IDMMS data structure, provided by TWRS Technical Integration, to allow software hooks into SWASOS's database(s) for querying and filtering data. Communication 1 inks between SWASDS's software system and TWRS Technica]

${ }^{1}$ Microsoft Windows is a trademark of Microsoft Corporation. 


\subsubsection{Audit}

The user interaction with TWRSView will involve queries against read-only files. The components of TWRSview will be protected from unauthorized change. No tracing or logging will be necessary.

\subsubsection{Transferability}

This system has the potential to be used for a variety of purposes. Coordination with PNL should occur to reduce the likelihood of duplication of services.

\subsubsection{Conversion}

Prototype implementation of TWRSview may include some conversion routines to Toad data for purposes of demonstration to management.

Production implementation will include the use of conversion routines for portions of the data.

Future enhancements will include dynamically linking to the applications that currently have a static interface with TWRSview. TWRS Technical Integration intend to work with the system owners of these applications to reach a common goal of dynamically linking the applications.

\subsubsection{Documentation}

Bocuments that will be provided by TWRS Technical Integration as part of the IDMMS project covering TWRSview are:

- Project Plan

- Test and Acceptance Plan

User Guide

TWRSview specific documents to be provided by TWRS Technical Integration are:

- Software Requirements Specification

- Discrepancy reporting

SWASDS will provide the following documents:

- System Design Description

The System Design Description (SDD) shall provide information necessary for TWRS Technical Integration to perform verification of SWASDS's software. The System Design Description will contain the following types of information: 
Integration's IDMMS shall be developed jointly between TWRS Technica] Integration and SWASDS.

\subsubsection{Communication Interfaces}

The software system must be adaptable to running on HLAN and the PNL network.

\subsection{PERFORMANCE REQUIREnENTS}

The TWRSview system will be a multi-user system. Initial TWRSview use will be limited to 20 concurrent users.

The application is intended to support many more users over time and the design will need to be scalable to accomplish this long term goal.

\subsubsection{Readability}

Graphics shall be clearly visible and readable on a 15 inch monitor with options to enlarge or decrease the size of the particular view. For all views, a sizing option will be made available on each screen.

\subsubsection{Response Times}

Graphic views shall take less than 15 seconds to display for 95 percent of the time. Data queries will complete within 1 minute for 95 percent of the queries requested. These required response times are based on a user accessing TWRSview via a standard 486/33 workstation with 8 megabytes of memory.

If a lower end machine is utilized response times may decrease. Also, the amount of other applications opened may decrease response time. For further information of recommended workstation configuration, see Section 3.4.2.

When the TWRSview application is processing a query or retrieving files, it must be clearly visible to the user that it is processing and is not ready to accept keyboard input.

\subsection{DESIGN CONSTRAINTS}

\subsubsection{Standards Compliance}

Workstations accessing TWRSview will be configured with the site standard End System Operating Environment (ESOE) configuration. ESOE is not a requirement for operation of TWRSview, but is a site standard for Hanford. 
This section outlines other general requirements that do not fit any of the categories previously addressed. Because of the ir unique nature, these requirements will be addressed in separate categories.

\subsubsection{Data}

TWRSview is a host based repository of data from multiple sources. The initial implementation will be to copy many sources of information in a manual mode. The goal is to directly access as many input sources as possible. The databases should be formatted such that STONEview can readily access the information. As the data sources grow, it will become necessary to have a directory of where information resides.

There are a variety of data types, including documents, models, images and factual data. TWRSview is intended to be adaptable to various data types and to be structured so expansion is easity accomplished.

At a minimum on implementation, the TWRSview file server must have 500 megabytes of disk space avaliable. User workstations must have 10 15 megabytes of disk space available.

\subsubsection{Operations}

The TWRSview server(s) will be maintained in a manner similar to all HLAN servers. A complete backup will be done weekly, supplemented by nightly backups of the changed data. If special maintenance activities are necessary, the users will be notified before the downtime occurs.

\subsubsection{Site Adaptation}

TWRSview is targeted for the Tank Waste Remediation Program currently, which will begin with a small user base.

In the future, TWRSview will be expanded to include other Hanford Site programs. All information will be included in the same application with menu options to select a specific program.

\subsubsection{Reliability and Recovery}

If the system fails, the users will not lose any data, as TWRSview is read only information. The only consequence will be unavailability for the duration of the down-time.

If there is an extreme system crash, which may include damage to the data storage device, it may be necessary to restore from backup. Network Operations will supply backups to the data. 
The data supporting the TWRSview application will reside on a file server with standard file server configuration. The application will generally reside on the users local hard drive.

A presentation will be made to the HANTAG board in regards to TWRSview as an application to run in a production environment. HANTAG's interests are in introducing new technologies used, how the application will integrate with the current environment, as well as a forum to ask questions and/or to raise issues and concerns.

A presentation will be made to the HANTRB board to request support on nightTy backups, file server maintenance, and HLAN support. HANTRB is a board that should be approached with in a few months of implementation.

\subsubsection{Resource Limitations}

CurrentTy STONEview does not have a network 1 tcense option. The licenses are for specific individual users. In the future, a network license managing capability, such as software metering, should be pursued for the network environment.

As a minimum, users need to have an IBM compatible $486 / 33$ workstation configured with 8 megabytes of memory. Frequent users of TWRSview are recommended to have 16 megabytes of memory.

\subsection{ATTRIBUTES}

\subsubsection{Availability}

The TWRSview system shall be available for users access from 6:00 am to 8:00 pm, seven days a week. It is understood that downt ime for maintenance, backups, and support will be necessary. This downtime should be kept to a minimum (preferably less than 10\%). Users will be notified prior to scheduled downtime.

\subsubsection{Maintenance}

During software development. SWASDS will be the custodians of the software and code. After implementation. TWRS Technical Integration will take ownership of the software and code.

During construction and after implementation, TWRS Technical Integration will be the custodians of the databases. maintenance.

Network Telecommunications will have ownership of file server hardware 


\subsubsection{Compatibility}

The TWRSview application is developed using STONEview software. The software must be compatible with the IDMMS and network environment. For further information, refer to Software Interfaces, Section 3.2.1.

\subsubsection{Data Integrity}

With the installation of TWRSview on a users workstation, some files are downloaded to the local hard disk. Periodically these files may become outdated. SWASDS will provide version checking such that when a user accesses TWRSview, they will be assured that if the files on the local hard disk are not the same as the server files, then the application will download the new files.

For long term data integrity to be intact, TWRS Technical Integration must work together with the interface application owners to dynamically link with the data sources. The data sources must also be pedigreed to ensure the most recent valid information is accessible.

\subsubsection{Ease of Use}

The TWRSview system will provide functions to allow easy access_and utilization of the system. The following capabilities will be provided to allow the system to be more intuitive (user friendly):

- Menu Driven

- Print Options

- Queries

- Help Messages

- Error Messages

- Mouse Functions
Menus will be provided for user interface with the system

An option to print various information described in the output section

There will be speedy results for queries

Informational messages will be provided to define or describe the purpose of each screen and provide status information pertaining to current operations

Error messages will be provided that will be unique and meaningful to each specific error. They will aid the user in recovering from error situations that might occur while reporting data

The majority of the functions performed will be via mouse point and click on either the tool bar or a highlighted area

\subsection{OTHER REQUIREMENTS}

